\title{
Density and distribution of megafauna at the Håkon Mosby mud volcano (the Barents Sea) based on image analysis
}

\author{
E. Rybakova (Goroslavskaya) ${ }^{1}$, S. Galkin ${ }^{1}$, M. Bergmann ${ }^{2}$, T. Soltwedel ${ }^{2}$, and A. Gebruk ${ }^{1}$ \\ ${ }^{1}$ P. P. Shirshov Institute of Oceanology, Russian Academy of Sciences, Nakhimovsky Pr., 36, Moscow 117997, Russia \\ ${ }^{2}$ Alfred Wegener Institute for Polar and Marine Research, Am Handelshafen 12, 27570, Bremerhaven, Germany \\ Correspondence to: E. Rybakova (Goroslavskaya) (gorolen@mail.ru)
}

Received: 22 November 2012 - Published in Biogeosciences Discuss.: 10 December 2012

Revised: 16 April 2013 - Accepted: 19 April 2013 - Published: 21 May 2013

\begin{abstract}
During a survey of the Håkon Mosby mud volcano (HMMV), located on the Bear Island fan in the southwest Barents Sea at $\sim 1250 \mathrm{~m}$ water depth, different habitats inside the volcano caldera and outside it were photographed using a towed camera platform, an Ocean Floor Observation System (OFOS). Three transects were performed across the caldera and one outside, in the background area, each transect was $\sim 2 \mathrm{~km}$ in length. We compared the density, taxa richness and diversity of nonsymbiotrophic megafauna in areas inside the volcano caldera with different bacterial mat and pogonophoran tubeworm cover. Significant variations in megafaunal composition, density and distribution were found between considered areas. Total megafaunal density was highest in areas of dense pogonophoran populations (mean 52.9 ind. $\mathrm{m}^{-2}$ ) followed by areas of plain light-coloured sediment that were devoid of bacterial mats and tube worms (mean 37.7 ind. $\mathrm{m}^{-2}$ ). The lowest densities were recorded in areas of dense bacterial mats (mean $\leq 1.4$ ind. $\mathrm{m}^{-2}$ ). Five taxa contributed to most of the observed variation: the ophiuroid Ophiocten gracilis, lysianassid amphipods, the pycnogonid Nymphon macronix, the caprellid Metacaprella horrida and the fish Lycodes squamiventer. In agreement with previous studies, three zones within the HMMV caldera were distinguished, based on different habitats and megafaunal composition: "bacterial mats", "pogonophoran fields" and "plain light-coloured sediments". The zones were arranged almost concentrically around the central part of the caldera that was devoid of visible megafauna. The total number of taxa showed little variation inside ( $24 \mathrm{spp}$.) and outside the caldera (26 spp.). The density, diversity and composition of megafauna varied substantially between plain lightcoloured sediment areas inside the caldera and the HMMV
\end{abstract}

background. Megafaunal density was lower in the background (mean 25.3 ind. $\mathrm{m}^{-2}$ ) compared to areas of plain light-coloured sediments inside the caldera. So the effect of the mud-volcano environment on benthic communities is expressed in increasing of biomass, changing of taxa composition and proportions of most taxonomic groups.

\section{Introduction}

Mud volcanoes are formations created by geo-excreted fluids. To date, more than 1700 mud volcanoes have been identified, of which some 800 are located offshore (Dimitrov, 2002). It has been estimated that more than 10000 mud volcanoes exist on continental shelves and abyssal plains (Ivanov et al., 1996; Milkov, 2000; Pimenov et al., 2000; Fleysher et al., 2001; Dimitrov, 2002; Kopf, 2002; Milkov et al., 2003). The processes leading to their formation include mud diapirism, tectonic compression, dehydration of clay minerals at depth or a rapid deposition of mass flows (Kohl and Roberts, 1994; Kopf, 2002; Huguen et al., 2004). Mud volcanoes are often associated with petroleum deposits, tectonic subduction zones and orogenic belts. They may form domes up to several kilometres in diameter and a height of several tens of meters above the adjacent seafloor (Vogt et al., 1999). Manifestations of mud volcanism are characterised by active seepages of fluids, gas plumes, enhanced heat flow, deposits of gas hydrates and unique chemoautotrophic communities (Damm and Budeus, 2003; Sauter et al., 2006). They are considered a significant source contributing to the marine methane budget (Jerosch et al., 2007) and, as such, of 


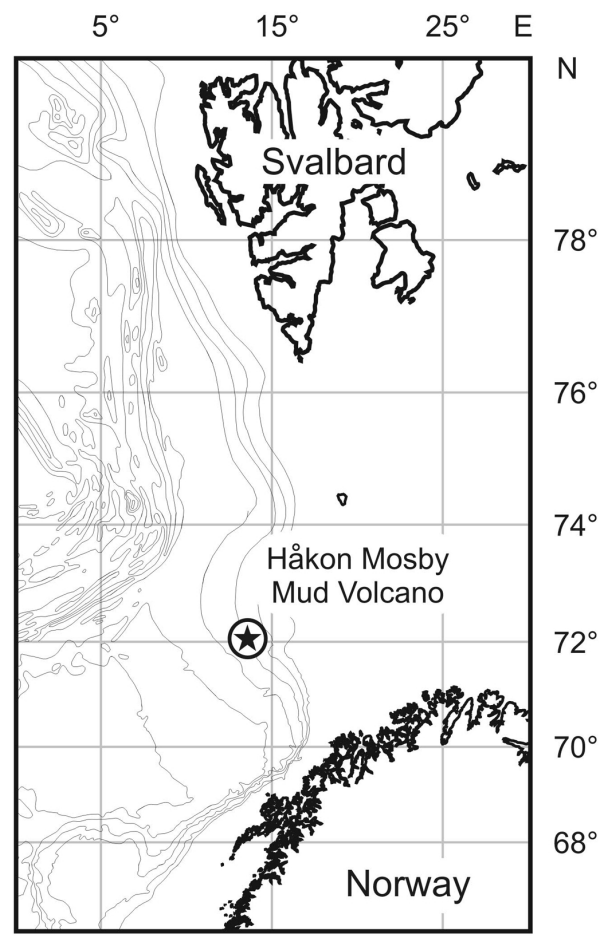

Fig. 1. Location of the Håkon Mosby mud volcano in the south-west Barents Sea.

greenhouse emissions to the hydrosphere and atmosphere (Milkov et al., 2003).

The Håkon Mosby mud volcano (HMMV) was discovered in 1989 during a regional side-scan sonar mapping survey (Crane and Solheim, 1995; Vogt et al., 1997; Milkov et al., 1999). To date, the HMMV is the only active mud volcano known from high northern latitude beyond the polar circle. Centred at ca. $72^{\circ} 00.25^{\prime} 4 \mathrm{~N}, 14^{\circ} 43.50^{\prime} \mathrm{E}$, it is situated on the Norwegian continental slope in the SW Barents Sea (Fig. 1) at ca. $1250 \mathrm{~m}$ water depth with a maximum elevation of $10 \mathrm{~m}$ and covers an area of ca. $2 \mathrm{~km}^{2}$ (Krupskaya et al., 2001).

A massive $6 \mathrm{~km}$ thick sediment pile that started to accumulate 30-40 million years ago after the continental break-up into what is now Greenland and Eurasia (Vogt et al., 1997; Hjelstuen et al., 1999), lies underneath the volcano. The formation of the volcano might have coincided with a submarine landslide during the late Pleistocene, $330000-200000 \mathrm{yr}$ ago (Vogt et al., 1999). Today, fluids rise from a sediment depth of 2-3 km through a conduit below the HMMV (Vogt et al., 1999). The age of the carbonate structures inside the modern caldera has been estimated as $11400 \mathrm{yr}$ BP (Lein and Ivanov, 2009).

During the R/V Håkon Mosby cruise in 1995, the mud volcano was mapped by $3.5 \mathrm{kHz}$ profiling, sediment coring and heat-flow measurements (Vogt et al., 1997). A gravity core from the flank of the structure contained gas and gas hydrate. High heat flow values $\left(337 \mathrm{mWm}^{-2}\right)$ were recorded. Together with observations of microbial methane $\left(\mathrm{CH}_{4}\right)$, hy-

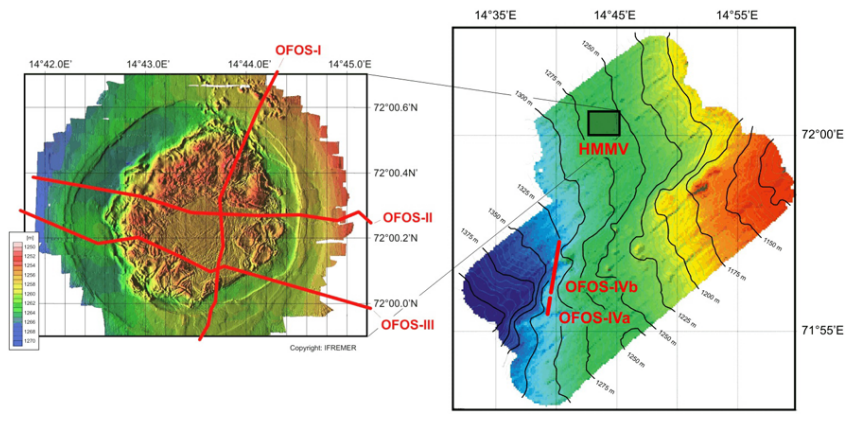

Fig. 2. Positions of the OFOS transects I, II and III taken across the Håkon Mosby mud volcano caldera area and the reference transect IV taken outside the volcano caldera.

drogen sulphide gas and $\mathrm{CH}_{4}$ gas hydrate, it was inferred that the structure was an active gas seep on the seafloor (Vogt et al., 1997).

Subsequent investigations using deep-towed side-scan sonar, sediment coring, CTD and heat flow measurements $8.8 \mathrm{kHz}$ profiling and seafloor photography during the expedition of the R/V Professor Logachev in 1996 - confirmed that the HMMV oozed mud and seeped gas (Lein et al., 1998, 1999; Eldholm et al., 1999). This expedition brought the first evidence of the presence of high benthic microbial activity and symbiotrophic fauna (two species of pogonophorans) associated with the mud volcano caldera (Pimenov et al., 1999; Smirnov, 2000).

The HMMV site was revisited in 1998 during the 40th cruise of the R/V Akademik Mstislav Keldysh with a joint team of scientists from Norway, Germany, the USA and Russia. Two Mir submersibles were used for six dives (Bogdanov et al., 1999). Detailed information about the geological features of mud volcano, gas hydrate distribution, biogeochemical processes in the sediment, water and biota were obtained (Lein et al., 2000; Pimenov et al., 2000). The general features of benthic communities were reported, based on camera observations and samples taken by submersibles (Gebruk et al., 2003). It was shown that the megabenthic community is dominated by two species of symbiotrophic siboglinid tube worms (pogonophorans): Sclerolinum contortum, later transferred to the genus Archeolinum (Smirnov, 2008), whose biomasses reached $435 \mathrm{~g} \mathrm{~m}^{-2}$ (Gebruk et al., 2003) and Oligobrachia haakonmosbiensis (Smirnov, 2000), later re-identified as $O$. webbi (Meunier et al., 2010) reached $350 \mathrm{~g} \mathrm{~m}^{-2}$ (Gebruk et al., 2003). Associations of benthic fauna with each pogonophoran species were described. The background community outside the caldera was dominated by the ophiuroids Ophiocten gracilis and Ophiopleura borealis. Pycnogonids (Colossendeis proboscidea), buccinid gastropods and asteroids were also present. The trophic relationships between species were discussed based on the $\delta^{13} \mathrm{C}$ data (Gebruk et al., 2003). 
During the expedition ARK XIX/3b of the German research icebreaker R/V Polarstern, with the French remotely operated vehicle (ROV) Victor 6000, in 2003, the microtopography of HMMV was determined, video observations of the seafloor were made and the sediment and water column was sampled (Klages et al., 2004). High-resolution bathymetric data, still photographs and video mosaics were integrated in a geographic information system (GIS). This allowed a detailed analysis of spatial patterns and quantification of biogeochemical habitats by geostatistical methods (Jerosch et al., 2007; Portnova et al., 2010). High concentrations of hydrogen sulphide and methane in the sediment at HMMV and other offshore mud volcanoes offer a specific habitat for microbiological and macrofaunal associations (Sibuet and Olu, 1998; Pimenov et al., 1999; Boetius et al., 2000, 2002; Hinrichs and Boetius, 2002; Soltwedel et al., 2005; De Beer et al., 2006; Sauter et al., 2006).

In previous studies three main habitat types have been identified in the HMMV: bacterial mats, pogonophoran fields and plain light-coloured sediments (Gebruk et al., 2003; Jerosch et al., 2007). Preliminary data were given on macroand megafauna associated with these habitats (Gebruk et al., 2003) and on meiofauna (Soltwedel et al., 2005; Portnova et al., 2010). Based on a photographic survey of the HMMV with a towed camera system, we compare composition, density and diversity of megafauna in habitats inside the volcano caldera with different density of seafloor coverage by bacterial mats and pogonophoran tube worms, and in habitats with different combinations of bacterial mats and pogonophorans, to identify an effect of a habitat type on the structure of benthic communities. Also we compare composition, diversity and density of megafauna inside and outside the volcano caldera, to determine an effect of the mud-volcano environment on benthic communities and to identify possible specialists of the HMMV.

\section{Material and methods}

\subsection{Photographic survey}

A photographic survey was carried out during the expedition ARK-XVIII/1b of the research icebreaker R/V Polarstern in August 2002 to the HMMV. Different habitats inside the volcano caldera and outside were photographed using a towed camera system (Ocean Floor Observation System, OFOS). Four OFOS transects were carried out in total: three across the caldera (I-III) and one outside the caldera (IV) to the south of volcano (Fig. 2). The length of each transect was ca. $2 \mathrm{~km}$ (Table 1).

The OFOS was equipped with a still camera (Benthos Inc.) and a black and white video camera (Deep-Sea Power and Light), two high-intensity discharge (HID) lights of $250 \mathrm{~W}$ each, strobes $\left(600 \mathrm{~W} \mathrm{~s}^{-1}\right)$ and three laser pointers. A triangle laser scale with $50 \mathrm{~cm}$ between lasers was used to determine the camera's footprint. The still camera was mounted to the frame in a vertical position to the seafloor. It was triggered automatically every $30 \mathrm{~s}$. Additional manually triggered images were taken when features of particular interest occurred in the field of view of the video camera, which was aligned with the still camera to help the winch operator adapting to bottom topography. The still camera was loaded with a $30 \mathrm{~m}$ Kodak Ektachrome 100 ASA film, allowing $\leq 800$ exposures (for more details see Soltwedel et al., 2009). The OFOS was towed at approximately 0.5 knots and a target altitude of $1.5 \mathrm{~m}$. From earlier OFOS deployments, this altitude has proven to be the optimal distance to the seafloor to achieve the best illumination and resolution of the images. The area of seafloor on the images ranged from 1 to $8 \mathrm{~m}^{2}$ owing to the ship's movement, in most cases it was $3-4 \mathrm{~m}^{2}$. Start and end positions of OFOS transects (from GPS fixes) and water depths along transects (from echo soundings) were obtained from the ship's data acquisition and management system.

\subsection{Image analysis and identification of megafauna}

In total 1604 film images were examined using a stereo microscope. Of these, 1045 images were used for statistical analyses. Among the analysed images, 894 were taken along the three transects across the caldera and 151 images along the transect outside the volcano. Images of unsatisfactory quality (with sediment clouds, too strong or low illumination, large or small distance from the bottom) were excluded from the analysis. All images within the volcano were taken in the soft-sediment environment. Part of images along the transect outside the volcano were taken on hard substrata (boulders, carbonate rocks and crust). Those images also were excluded from the analysis because the aim of our study was to compare fauna from similar sediment environments. All visible nonsymbiotrophic megafauna were counted and identified to the lowest possible taxonomic level. Taxonomic identifications were made with the assistance of experts (see Acknowledgements). We used the category "morphospecies" for megafauna identified only to high taxonomic level. Recurring biological objects that could not be assigned to any taxa were indicated as "morphotypes". It is possible that some morphotypes (and morphospecies) include several species. Overall, 31 categories (29 species/morphospecies and 2 morphotypes of megafauna) were identified and quantified and used in multivariate statistical analyses and estimations of megafaunal density (Table 2). Density was not determined for the two pogonophorans, Oligobrachia webbi and Archeolinum contortum. For these and for bacterial mats we estimated the degree of seafloor area coverage using the laser scale. Identification and ground-truthing was aided by previously collected material and samples taken outside the caldera using an Agassiz trawl and inside the caldera using a box corer, ROV, trap lander and baited traps. For details on gears and deployments see Table 1 in Supplement and Pimenov et al. (1999), Bergmann et al. (2009) and Hildebrandt 
Table 1. Details of OFOS transects. Transects I, II and III - inside the caldera, transect IVa and b - reference site.

\begin{tabular}{|c|c|c|c|c|c|c|c|c|c|c|c|c|}
\hline \multirow[t]{2}{*}{ Gear } & \multirow{2}{*}{$\begin{array}{l}\text { Transect/ } \\
\text { deploy- } \\
\text { ment }\end{array}$} & \multirow[t]{2}{*}{$\begin{array}{r}\text { Date, } \\
\text { Aug. } 2002\end{array}$} & \multicolumn{4}{|c|}{$\begin{array}{c}\text { Position, } \\
\text { north-east }\left({ }^{\circ}\right)\end{array}$} & \multirow{2}{*}{$\begin{array}{r}\text { Survey } \\
\text { time } \\
(\min )\end{array}$} & \multicolumn{2}{|c|}{$\begin{array}{c}\text { Water } \\
\text { depth }(m)\end{array}$} & \multirow{2}{*}{$\begin{array}{r}\text { Total } \\
\text { no. of } \\
\text { images }\end{array}$} & \multirow{2}{*}{$\begin{array}{r}\text { No. of } \\
\text { images } \\
\text { analysed }\end{array}$} & \multirow{2}{*}{$\begin{array}{r}\text { Total area } \\
\text { coveree } \\
\text { by image } \\
\left(\mathrm{m}^{2}\right.\end{array}$} \\
\hline & & & \multicolumn{2}{|c|}{ Start } & \multicolumn{2}{|c|}{ End } & & Start & End & & & \\
\hline OFOS & I & 21 & 72.01 & 14.44 & 71.60 & 14.44 & 105 & 1261 & 1268 & 401 & 256 & 1003 \\
\hline OFOS & II & 21 & 72.00 & 14.41 & 72.00 & 14.45 & 130 & 1284 & 1254 & 391 & 233 & 1042 \\
\hline OFOS & III & $22 / 23$ & 72.00 & 14.42 & 71.60 & 14.46 & 94 & 1278 & 1254 & 562 & 405 & 1480 \\
\hline \multirow[t]{2}{*}{ OFOS } & IVa & 21 & 71.56 & 14.39 & 71.56 & 14.39 & 31 & 1329 & 1308 & 36 & 24 & 93 \\
\hline & $\mathrm{IVb}$ & 21 & 71.57 & 14.40 & 71.56 & 14.39 & 160 & 1325 & 1313 & 196 & 127 & 389 \\
\hline
\end{tabular}

et al. (2011). For a complete list of species found inside and outside the HMMV caldera see Table 2 in Supplement.

\subsection{Data analysis}

The number of organisms on each image was converted to individuals per $\mathrm{m}^{2}$ (density). Non-metric, multidimensional scaling (MDS) plots were generated for each transect inside the caldera based on the Bray-Curtis similarity coefficient using the PRIMER v6 programme and square root transformed species density matrices. Square root transformation of densities was used to buffer the influence of most abundant taxa.

Analysis of similarity (ANOSIM) was used to assess the significance of differences among images from areas with different percent cover of bacterial mats, pogonophorans or images with different combinations of percent cover of bacterial mats and pogonophorans. Contribution of species to similarity of different groups of images was calculated using the SIMPER subroutine of PRIMER v6 (Clarke and Gorley, 2006). ANOSIM and SIMPER were used for comparing images taken on the plain light-coloured sediment inside the caldera and images outside the caldera.

Combined data from three OFOS transects over the caldera were used for the calculation of the total megafaunal density ( \pm standard deviation) and the mean taxa densities ( \pm standard deviation) in areas with different coverage by bacterial mats or pogonophorans. The relative contributions of the most abundant taxa to the total density in different areas were calculated. Additionally the mean taxa densities were estimated for areas with different combinations of bacterial mats and pogonophorans.

The following diversity indices were applied to combined data of the three OFOS transects to describe megafaunal assemblages: Pielou's evenness $\left(J^{\prime}\right)$, Shannon-Wiener diversity $\left(H^{\prime}\right)\left(\log _{2}\right)$ and Simpson's diversity $(1-\lambda)$ in areas with different coverage by bacterial mats or pogonophorans. Similar calculations were performed for transect IV taken outside the caldera. Taxa richness in different areas was compared based on an equal number of randomly selected images.

We compared total megafaunal densities, mean taxa densities and diversity on images with different coverage by bacterial mats or pogonophorans overall using a KruskalWallis test (Minitab 16 software). Pairwise comparisons of different areas were performed using the Mann-Whitney $U$ Test and Bonferroni corrections of $p=0.05 n^{-1}$, where $n$ is number of comparisons (comparison of bacterial mat sites: $n=10, p=0.005$; comparison of pogonophoran sites: $n=6, p=0.00833$; comparison of area of plain lightcoloured sediments and pogonophoran sites: $n=10, p=$ 0.005) (Minitab 16). Comparisons of diversities were done for the equal number of randomly selected images from each area because diversity indices are based on the taxa richness, which is affected by the number of images analysed. Similarly, images from outside the caldera were compared with images from the light-coloured sediments using the Mann-Whitney $U$ Test.

Spearman's rank correlations were used to compare taxa richness, total megafaunal densities, diversity indices with coverage of bacterial mats or pogonophorans.

\section{Results}

Twenty-four species/morphospecies were recorded from three OFOS transects taken across the HMMV caldera (transects I, II and III). Thirteen taxa were identified to species or genus, others were assigned to higher taxa (Table 2). The following higher taxa were present: Cnidaria (2 species), Nemertea (1), Polychaeta (1), tube worms Siboglinidae (2), Gastropoda (1), Bivalvia (1), Pycnogonida (2), Crustacea (4), Ophiuroidea (2), Crinoidea (1), Asteroidea (3), Holothuroidea (1), Echinoidea (1), and at least two species of fish: Lycodes squamiventer and Amblyraja hyperborea. Samples taken for ground-truthing revealed 16 additional species (Table 2 in Supplement). Echinoderms accounted for the majority of taxa (8 species/morphospecies).

\subsection{Megafauna in areas with different seafloor coverage by bacterial mats and pogonophorans}

\subsubsection{Bacterial mat sites}

We used the following five categories for the seafloor area coverage by bacterial mats: $0 \%, 0-10 \%, 10-50 \%, 50-80 \%$ and $80-100 \%$. ANOSIM revealed significant differences in megafaunal composition and density of images with no bacterial mats at all $(0 \%)$ from images with bacterial mats 
Table 2. Megafauna and other categories recorded on OFOS transects.

\begin{tabular}{|c|c|c|c|}
\hline $\begin{array}{l}\text { High taxon/ } \\
\text { object }\end{array}$ & $\begin{array}{l}\text { Species/morphospecies/ } \\
\text { morphotype/category }\end{array}$ & HMMV & Background \\
\hline \multirow[t]{2}{*}{ Porifera } & cf. Stylocordyla borealis & & + \\
\hline & Grey form (?Demospongia) & & + \\
\hline \multicolumn{4}{|l|}{ Cnidaria } \\
\hline \multirow[t]{3}{*}{ Anthozoa } & Purple form (cf. Edwardsiida) & + & \\
\hline & Small pinkish (cf. Hormathiidae) & + & \\
\hline & Undetermined & & + \\
\hline \multirow[t]{2}{*}{ Nemertea } & cf. Nipponnemertes pulchra & & + \\
\hline & nemertini-like worm & + & + \\
\hline \multicolumn{4}{|l|}{ Annelida } \\
\hline \multirow[t]{4}{*}{ Polychaeta } & Oligobrachia webbi & + & \\
\hline & Archeolinum contortum & + & \\
\hline & cf. Polynoidae & & + \\
\hline & cf. Sabellidae (tubes) & + & + \\
\hline \multicolumn{4}{|l|}{ Mollusca } \\
\hline Gastropoda & cf. Buccinidae & + & + \\
\hline Bivalvia & Whitish burrowing form & + & + \\
\hline \multicolumn{4}{|l|}{ Arthropoda } \\
\hline \multirow[t]{2}{*}{ Pycnogonida } & cf. Nymphon macronix & + & + \\
\hline & cf. Collossendeis proboscidea & + & + \\
\hline \multicolumn{4}{|l|}{ Crustacea } \\
\hline \multirow[t]{2}{*}{ Amphipoda } & cf. Metacaprella horrida & + & + \\
\hline & cf. Lysianassidae & + & + \\
\hline ?Isopoda & Small whitish form & + & + \\
\hline Decapoda & Bentho-pelagic redish form & + & + \\
\hline \multicolumn{4}{|l|}{ Echinodermata } \\
\hline \multirow[t]{2}{*}{ Ophiuroidea } & Ophiocten gracilis & + & + \\
\hline & Ophiopleura borealis & + & + \\
\hline Crinoidea & Bathycrinus cf. carpenteri & + & + \\
\hline \multirow[t]{5}{*}{ Asteroidea } & cf. Pontaster & + & + \\
\hline & Whitish form (cf. Bathybiaster) & + & + \\
\hline & Flat pentagonal form, short rays & + & \\
\hline & Short arms (Hymenaster type) & & + \\
\hline & White short arms & & + \\
\hline Holothuroidea & cf. Elpidia glacialis & + & \\
\hline Echinoidea & Undetermined & + & + \\
\hline \multicolumn{4}{|l|}{ Pisces } \\
\hline Rays & Amblyraja hyperborea & + & \\
\hline Zoarcidae & Lycodes squamiventer & + & + \\
\hline Unknown, morphotype1 & Small brown bushes (?hydroids) & & + \\
\hline Unknown, morphotype 2 & $\begin{array}{l}\text { Small white sedentary forms } \\
\text { (?anemones, sponges) }\end{array}$ & & + \\
\hline \multirow[t]{6}{*}{ Bacterial mat } & Area cover $(\%)$ & & \\
\hline & 0 & + & + \\
\hline & $<10$ & + & \\
\hline & $10-50$ & + & \\
\hline & $50-80$ & + & \\
\hline & $>80$ & + & \\
\hline Siboglinidae & Area cover $(\%)$ : & & \\
\hline \multirow[t]{4}{*}{ Archeolinum contortum } & 0 & + & + \\
\hline & $<10$ & + & \\
\hline & $10-50$ & + & \\
\hline & $>50$ & + & \\
\hline
\end{tabular}




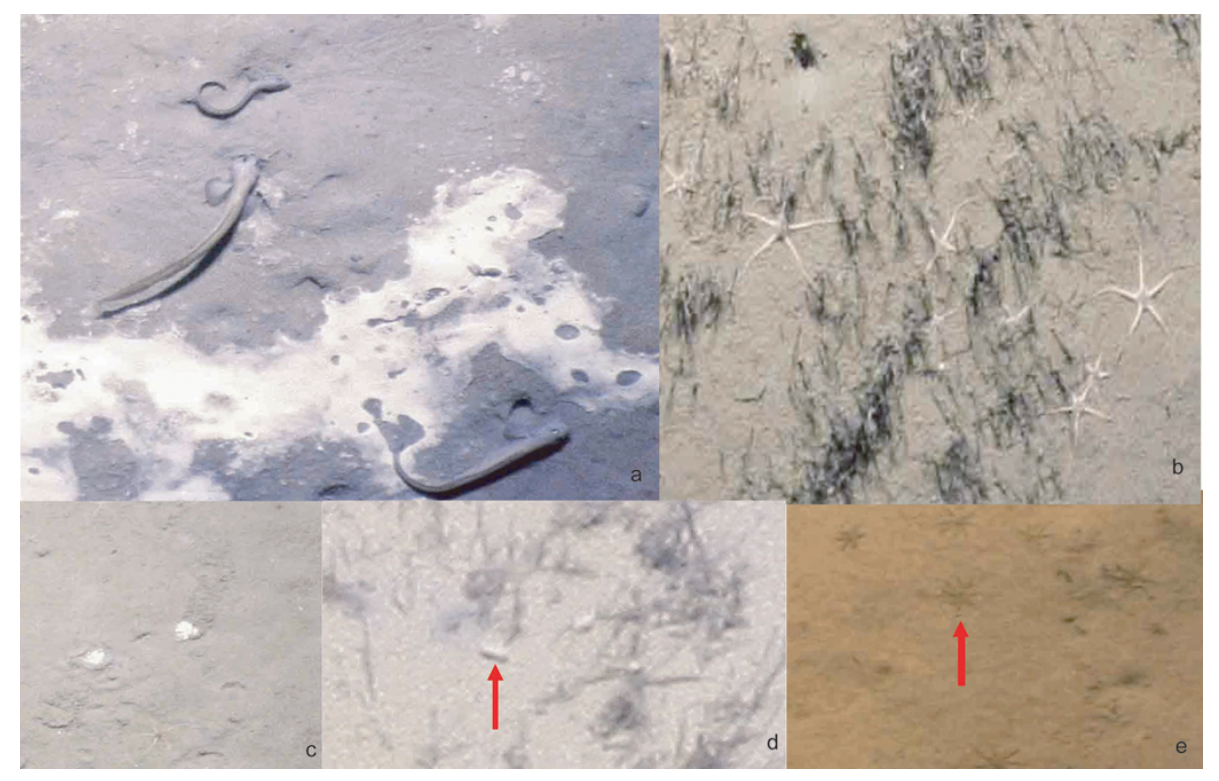

Fig. 3. Most abundant species on the OFOS images. (a) Lycodes squamiventer (Pisces), (b) Ophiocten gracilis (Ophiuroidea), (c) Bivalvia gen. sp (whitish form), (d) Lysianassidae (Amphipoda), (e) Nymphon macronix (Pycnogonida).

present and did not reveal significant differences in megafaunal composition and density between images with different coverage of bacterial mats (Global $R=0.538, p=0.001$ ).

SIMPER indicated that five species contributed most to the separation of the mat coverage groups: Ophiocten gracilis, lysianassid amphipods, Nymphon macronix, Metacaprella horrida and Lycodes squamiventer (Fig. 3). The mean densities of these species in areas of different coverage by bacterial mats are presented in Table 4 . The most notable differences in density were found in $O$. gracilis and $L$. squamiventer. Ophiocten densities decreased significantly from $37.9 \pm 38.7$ ind. $\mathrm{m}^{-2}$ in the absence if mats to $1.3 \pm 5.3$ ind. $\mathrm{m}^{-2}$ when bacterial mats $(<10 \%$ coverage $)$ appeared $(M-W: W=271840.0, p<0.00001)$. By contrast, the density of $L$. squamiventer increased from $0.1 \pm 0.3$ to $1.2 \pm 0.6$ ind. $\mathrm{m}^{-2}$ when bacterial mats were present (coverage $>80 \%$ ). Fish densities on bacterial mats were significantly different between bacterial mats $>80 \%$ and all other bacterial mat categories ( $M$ - $W$ test, $p<0.00001)$ with highest densities recorded in areas of $80 \%$ bacterial coverage and lowest in areas $10 \%$ coverage.

Total megafaunal densities sharply decreased from $43.7 \pm 44.3$ ind. $\mathrm{m}^{-2}$ to $4.7 \pm 8.0$ ind. $\mathrm{m}^{-2}$ when the coverage by bacterial mats increased from $0 \%$ to $10 \%$. The Kruskal-Wallis test indicated significant differences in total megafaunal densities in areas of different coverage by bacterial mats $(K-W: H=417.90, p<0.0001, \mathrm{DF}=4)$. The pairwise Mann-Whitney $U$ Test revealed significant differences in the total density of megafauna between images from areas with the following bacterial mat coverage: $0 \%$ and $<10 \%(M-W: W=269903.5, p<0.00001)$. The test did not reveal significant differences between images from ar- eas with bacterial mat coverage $>10 \%(p>0.005)$. Total megafaunal densities were significantly and negatively correlated with coverage by bacterial mats (Table 5).

Taxa richness gradually decreased with increasing coverage by bacterial mats: from 24 taxa to 3 (Table 3). Taxa richness was significantly and negatively correlated with coverage by bacterial mats (Table 5). Evenness and diversity were significantly higher in areas without bacterial mats $\left(J^{\prime}=0.3 ; H^{\prime}=0.4\right.$ and $\left.1-\lambda=0.2\right)$ and with bacterial mat coverage of up to $10 \%\left(J^{\prime}=0.4 ; H^{\prime}=0.4\right.$ and 1 $\lambda=0.2)$ compared to areas with bacterial mat coverage exceeding $10 \%\left(J^{\prime} \leq 0.2 ; H^{\prime} \leq 0.2\right.$ and $\left.1-\lambda \leq 0.1\right)\left(M-W: J^{\prime}\right.$ : $W=8116.0-8563.5, \quad p \leq 0.0006 ; H^{\prime}: W=8281-8734.5$, $p<0.0001 ; 1-\lambda: W=8261.5-8672.0, p<0.0001)$. Evenness and diversity did not differ significantly in areas with bacterial mat $<10 \%$ and in areas without bacterial mats $\left(M-W: J^{\prime}: W=29850.0, p=0.8592 ; H^{\prime}: W=29057.5\right.$, $p=0.3034 ; 1-\lambda: W=29277.5, p=0.4279)$ (Table 3). Evenness and diversity were negatively correlated with coverage by bacterial mats, but correlations were not statistically significant (Table 5).

\subsubsection{Pogonophoran sites}

For the seafloor area coverage by pogonophoran tube worms, we used the following four categories: $0 \%, 0-10 \%, 10-50 \%$ and $50-100 \%$. ANOSIM indicated significant differences in megafaunal composition and density of images without pogonophorans $(0 \%)$ from images with pogonophorans present $(>0 \%)$ and of images with pogonophoran coverage $<10 \%$ from those with coverage $10-50 \%$. Significant differences were not observed between the categories $0-10 \%$ 
Table 3. Indices of megafaunal diversity and megafaunal density (ind. $\mathrm{m}^{-2}$ ) in areas of different coverage by bacterial mats and pogonophorans inside the HMMV caldera (OFOS transects I, II and III combined) and the background (OFOS transect IV).

\begin{tabular}{|c|c|c|c|c|c|c|c|c|c|c|c|}
\hline \multirow{2}{*}{ Index } & \multicolumn{5}{|c|}{ Bacterial mats (BM) } & \multicolumn{4}{|c|}{ Pogonophorans (P) } & \multirow{2}{*}{$\begin{array}{r}\mathrm{BM} \text { and } \mathrm{P} \\
0 \%\end{array}$} & \multirow[t]{2}{*}{ Background } \\
\hline & $0 \%$ & $<10 \%$ & $10-50 \%$ & $50-80 \%$ & $>80 \%$ & $0 \%$ & $<10 \%$ & $10-50 \%$ & $>50 \%$ & & \\
\hline Number of images & 576 & 173 & 84 & 49 & 12 & 531 & 84 & 101 & 178 & 367 & 151 \\
\hline Total species $(S)$ & 24 & 19 & 10 & 9 & 3 & 23 & 17 & 18 & 19 & 23 & 26 \\
\hline Pielou's evenness $\left(J^{\prime}\right)$ & 0.3 & 0.4 & 0.2 & 0.2 & 0.2 & 0.2 & 0.4 & 0.6 & 0.5 & 0.2 & 0.4 \\
\hline Shannon diversity $\left(H^{\prime}\right)$ & 0.4 & 0.4 & 0.2 & 0.2 & 0.2 & 0.2 & 0.5 & 0.7 & 0.6 & 0.2 & 0.6 \\
\hline Simpson diversity $(1-\lambda)$ & 0.2 & 0.2 & 0.1 & 0.1 & 0.1 & 0.1 & 0.3 & 0.4 & 0.3 & 0.1 & 0.3 \\
\hline $\begin{array}{l}\text { Total } \\
\text { megafaunal } \\
\text { density }( \pm S D)\end{array}$ & $43.7 \pm 44.3$ & $4.7 \pm 8.0$ & $1.9 \pm 3.2$ & $1.4 \pm 2.0$ & $1.3 \pm 0.7$ & $26.4 \pm 25.1$ & $16.7 \pm 15.8$ & $14.6 \pm 28.7$ & $52.9 \pm 71.5$ & $37.7 \pm 22.3$ & $25.3 \pm 21.0$ \\
\hline
\end{tabular}

Table 4. Mean density (ind. $\mathrm{m}^{2}$ ) and standard deviations (SD) of the most abundant taxa in areas of different coverage (\%) by bacterial mats and pogonophorans. Data from OFOS transects I, II and III combined and from the background transect IV.

\begin{tabular}{|c|c|c|c|c|c|c|c|c|c|c|c|c|c|c|c|c|c|c|c|c|c|c|}
\hline \multirow[t]{3}{*}{ Taxon/Morphotype } & \multicolumn{10}{|c|}{ Bacterial mats (BM) } & \multicolumn{8}{|c|}{ Pogonophorans (P) } & \multirow{2}{*}{\multicolumn{2}{|c|}{$\begin{array}{c}\mathrm{BM} \text { and } \mathrm{P} \\
0 \%\end{array}$}} & \multicolumn{2}{|c|}{ Background } \\
\hline & \multicolumn{2}{|c|}{$0 \%$} & \multicolumn{2}{|c|}{$<10 \%$} & \multicolumn{2}{|c|}{$10-50 \%$} & \multicolumn{2}{|c|}{$50-80 \%$} & \multicolumn{2}{|c|}{$>80 \%$} & \multicolumn{2}{|c|}{$0 \%$} & \multicolumn{2}{|c|}{$<10 \%$} & \multicolumn{2}{|c|}{$10-50 \%$} & \multicolumn{2}{|c|}{$>50 \%$} & & & & \\
\hline & Mean & SD & Mean & SD & Mean & SD & Mean & SD & Mean & SD & Mean & SD & Mean & SD & Mean & SD & Mean & SD & Mean & SD & Mean & SD \\
\hline $\begin{array}{l}\text { Ophiocten } \\
\text { gracilis }\end{array}$ & 37.9 & 38.7 & 1.3 & 5.3 & 0.1 & 0.4 & 0.1 & 0.4 & 0 & 0 & 24.7 & 24.4 & 11.9 & 14.1 & 6.5 & 19.9 & 41.4 & 62.2 & 35.7 & 21.7 & 22.3 & 21.8 \\
\hline $\begin{array}{l}\text { Amphipoda } \\
\text { Lysianassidae }\end{array}$ & 3.7 & 7.9 & 1.6 & 3.0 & 0.5 & 1.7 & 0.2 & 1.2 & 0 & 0 & 0.3 & 1.3 & 2.5 & 3.5 & 4.9 & 6.8 & 8.9 & 11.2 & 0.5 & 1.6 & 0.3 & 0.7 \\
\hline $\begin{array}{l}\text { Metacaprella } \\
\text { horrida }\end{array}$ & 0.3 & 1.1 & 0.1 & 0.4 & 0.1 & 0.5 & 0 & 0 & 0 & 0 & 0.0 & 0.1 & 0.1 & 0.5 & 0.1 & 0.5 & 0.9 & 1.9 & 0.0 & 0.1 & 0.0 & 0.0 \\
\hline $\begin{array}{l}\text { Nymphon } \\
\text { macronix }\end{array}$ & 1.2 & 3.5 & 0.9 & 3.1 & 0.4 & 1.6 & 0.2 & 0.6 & 0.1 & 0.3 & 0.7 & 2.3 & 1.4 & 3.3 & 2.3 & 6.0 & 1.0 & 2.9 & 0.9 & 2.7 & 0.0 & 0.1 \\
\hline $\begin{array}{l}\text { Lycodes } \\
\text { squamiventer }\end{array}$ & 0.1 & 0.3 & 0.5 & 0.6 & 0.8 & 0.7 & 0.8 & 0.6 & 1.2 & 0.6 & 0.3 & 0.6 & 0.2 & 0.5 & 0.2 & 0.4 & 0.2 & 0.4 & 0.1 & 0.3 & 0.0 & 0.1 \\
\hline $\begin{array}{l}\text { Bivalvia } \\
\text { (whitish form) }\end{array}$ & 0.1 & 0.3 & 0.1 & 0.3 & 0.0 & 0.1 & 0.0 & 0.1 & 0 & 0 & 0.1 & 0.2 & 0.2 & 0.3 & 0.3 & 0.5 & 0.1 & 0.3 & 0.1 & 0.2 & 0.1 & 0.2 \\
\hline $\begin{array}{l}\text { Polychaeta } \\
\text { tubes (cf. } \\
\text { Sabellidae) }\end{array}$ & 0 & 0 & 0 & 0 & 0 & 0 & 0 & 0 & 0 & 0 & 0 & 0 & 0 & 0 & 0 & 0 & 0 & 0 & 0 & 0 & 1.0 & 1.0 \\
\hline $\begin{array}{l}\text { Porifera cf. } \\
\text { Stylocordyla borealis }\end{array}$ & 0 & 0 & 0 & 0 & 0 & 0 & 0 & 0 & 0 & 0 & 0 & 0 & 0 & 0 & 0 & 0 & 0 & 0 & 0 & 0 & 1.0 & 1.2 \\
\hline $\begin{array}{l}\text { Morphotype } 2 \\
\text { (white } \\
\text { sedentary } \\
\text { form) }\end{array}$ & 0 & 0 & 0 & 0 & 0 & 0 & 0 & 0 & 0 & 0 & 0 & 0 & 0 & 0 & 0 & 0 & 0 & 0 & 0 & 0 & 0.1 & 0.3 \\
\hline
\end{tabular}

and $50-100 \%, 10-50 \%$ and $50-100 \%$ (Global $R=0.136$, $p=0.001)$.

SIMPER revealed that five species contributed most to the separation of groupings of images with different coverage by pogonophorans: $O$. gracilis, lysianassid amphipods, N. macronix, M. horrida and L. squamiventer (Fig. 3). The mean densities of these species in areas of different pogonophoran coverage are presented in Table 4. Most notable are differences shown by $O$. gracilis, lysianassid amphipods and M. horrida. Densities of these species increased with increasing coverage by pogonophorans from $<10 \%$ to $>50 \%$ : O. gracilis densities from $11.9 \pm 14.1$ ind. $\mathrm{m}^{-2}$ with $<10 \%$ pogonophoran cover to $41.4 \pm 62.2$ ind. $\mathrm{m}^{-2}$ with $>50 \%$ pogonophoran. A similar comparison with lysianassid amphipods showed an increase from $2.5 \pm 3.5$ to $8.9 \pm 11.2$ ind. $\mathrm{m}^{-2}$ under the same conditions and an increase in M. horrida from $0.1 \pm 0.5$ to $0.9 \pm 1.9$ ind. $\mathrm{m}^{-2}$. Most pronounced were the differences in the lysianassid amphipods and $M$. horrida $(M-W: W=25731.5, p<$ $0.00001 ; W=8977.0, p=0.0004$, respectively. Significant differences in Ophiocten densities were found only be- tween areas with pogonophoran coverage of $10-50 \%$ and $>50 \%$ : $6.5 \pm 19.9$ and $41.4 \pm 62.2$ ind. $\mathrm{m}^{-2}$, respectively $(M-W: W=26805.0, p<0.001)$. Significant differences in Ophiocten densities were not found between areas with pogonophoran coverage $<10 \%$ and $>50 \%$ : $11.9 \pm 14.1$ and $41.4 \pm 62.2$ ind. $\mathrm{m}^{-2}$, respectively $(M-W: W=9625.0$, $p=0.0134$ ).

Total megafaunal densities increased from $16.7 \pm 15.8$ ind. $\mathrm{m}^{-2}$ to $14.6 \pm 28.7$ ind. $\mathrm{m}^{-2}$ with increasing pogonophoran coverage from $<10 \%$ to $10-50 \%$ and total megafaunal densities increased to $52.9 \pm 71.5$ ind. $\mathrm{m}^{-2}$ with increasing pogonophoran coverage from 10-50\% to $>50 \%$. There were significant differences in total megafaunal densities between areas with different coverage by pogonophorans ( $K-W: H=20.81, p<0.0001, \mathrm{DF}=3$ ). Pairwise comparisons revealed significant differences in the total megafaunal densities only between images with $10-50 \%$ and $>50 \%$ of coverage by tube worms $(M-W: W=27782.5, p<0.0014)$. Total megafaunal densities were slightly positively correlated with coverage by pogonophorans (Table 5). 
Table 5. Spearman's rank correlations between taxa richness, total megafaunal densities and diversity indices with coverage of bacterial mats or pogonophorans. ${ }^{*} p<0.05$.

\begin{tabular}{lrr}
\hline & $\begin{array}{r}\text { Bacterial } \\
\text { mats }(\%)\end{array}$ & $\begin{array}{r}\text { Pogonophorans } \\
(\%)\end{array}$ \\
\hline Pielou's evenness $\left(J^{\prime}\right)$ & -0.783 & 0.8 \\
Shannon diversity $\left(H^{\prime}\right)$ & -0.866 & 0.8 \\
Simpson diversity $(1-\lambda)$ & -0.866 & 0.632 \\
Total megafaunal density & $-1^{*}$ & 0.2 \\
Total species $(S)$ & $-1^{*}$ & -0.2 \\
\hline
\end{tabular}

There were no significant differences in the taxa richness of different areas when equal numbers of images were considered. Taxa richness was slightly negatively correlated with coverage by pogonophorans (Table 5). Taxa richness was 1718 (Table 3). Evenness and diversity were not significantly higher in areas with coverage by pogonophorans of $<10 \%$ $\left(J^{\prime}=0.4 ; H^{\prime}=0.5\right.$ and $\left.1-\lambda=0.3\right)$ and $>50 \%\left(J^{\prime}=0.5\right.$; $H^{\prime}=0.6$ and $\left.1-\lambda=0.3\right)\left(M-W: \mathrm{J}^{\prime}: W=7841.5, p=0.0184\right.$; $\left.H^{\prime}: W=7808.5, p=0.0243 ; 1-\lambda: W=7911.5, p=0.0099\right)$ (Table 3 ). Evenness and diversity were positively correlated with coverage by pogonophorans, but correlations were not statistically significant (Table 5).

\subsubsection{Area without bacterial mats and pogonophorans (plain light-coloured sediments)}

ANOSIM revealed significant differences in the species composition of images taken from light-coloured sediments and pogonophoran settlements (Global $R=0.315$, $p=0.001)$. SIMPER indicated two species contributing most to the separation of images from these areas: O. gracilis and lysianassid amphipods. The mean Ophiocten densities were significantly lower on the plain light-coloured sediment $\left(35.7 \pm 21.7\right.$ ind $\left.\mathrm{m}^{-2}\right)$ than in areas with a coverage by pogonophorans exceeding $50 \%(M-W: W=108228.5$, $p<0.00001)$, but higher than in areas with a coverage of $0-50 \%(M-W: W=92895.0-100705.5, p<0.00001)$. The mean lysianassid densities were significantly lower on light-coloured sediments than in areas with pogonophorans $(M-W: p<0.00001)$ (Table 4).

Mean megafaunal densities were significantly lower on light-coloured sediments $\left(37.7 \pm 22.3\right.$ ind. $\left.\mathrm{m}^{-2}\right)$ compared with areas exceeding $50 \%$ pogonophoran coverage ( $M-W: W=107801.5, p=0.0008)$, but significantly higher than in areas of $0-50 \%$ pogonophoran coverage $(M-W$ : $W=100773.0-93744.0, p<0.00001)$.

Taxa richness was slightly higher on lightcoloured sediments than in areas with pogonophorans (20 compared to 17-18). Evenness and diversity of light-coloured sediments were significantly lower $\left(J^{\prime}=0.2 ; H^{\prime}=0.2\right.$ and $\left.1-\lambda=0.1\right)$ than those inhabited by pogonophorans $(M-W: p<0.00001)$ (Table 3$)$.

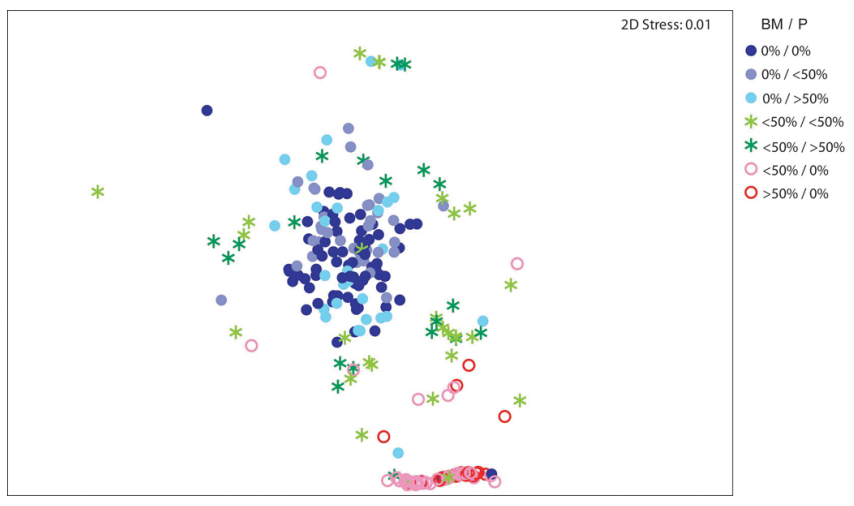

Fig. 4. Similarity between images with combinations of different coverage by bacterial mats (BM) and pogonophorans (P) (MDS plot, transect I).

\subsubsection{Areas with combinations of different coverage by bacterial mats and pogonophorans}

Three variations of seafloor coverage were considered both for bacterial mats and tube worms: 0\%, 0-50\%, 50$100 \%$. ANOSIM revealed significant differences (Global $R=0.551, p=0.001)$ in megafaunal composition and density of images with all combinations of areas with bacterial mats and pogonophorans except two combinations: (1) bacterial mats $0-50 \%$, pogonophorans $0-50 \%$ and bacterial mats $0-50 \%$, pogonophorans $50-100 \%$; (2) bacterial mats 0-50\%, pogonophorans $0 \%$ and bacterial mats $50-100 \%$, pogonophorans $0 \%$.

Figure 4 indicates two groups of images: (1) without bacterial mats and (2) with bacterial mats but without pogonophorans. Images with bacterial mats and pogonophorans fell out of revealed groupings.

SIMPER revealed that five species contributed most to the separation of groupings of images with different combination of areas with bacterial mats and pogonophorans: $O$. gracilis, lysianassid amphipods, $N$. macronix, M. horrida and $L$. squamiventer (Fig. 3).

Relatively high densities of megafauna (16-98 ind. $\mathrm{m}^{-2}$ ) were observed in areas without bacterial mats. Highest densities were recorded in areas devoid of bacterial mats but with dense settlements of tube worms (50-100\%). Areas devoid of bacterial mats and pogonophorans were characterised by high ophiuroid densities ( 33.1 ind. $\mathrm{m}^{-2}$ ) but relatively low densities of other taxa $\left(0.8\right.$ ind. $\left.\mathrm{m}^{-2}\right)$. Areas devoid of bacterial mats but with dense coverage by tube worms $(>50 \%)$ haboured the highest ophiuroid densities $\left(77.7\right.$ ind. $\left.\mathrm{m}^{-2}\right)$ and other taxa (21.2 ind. $\mathrm{m}^{-2}$ ) (Fig. 5).

Relative contributions of the most abundant taxa to the total density in areas with different coverage by bacterial mats and tube worms are shown on Fig. 6. Fish accounted for $86 \%$ of the total density $\left(0.8 \pm 0.6\right.$ ind. $\left.\mathrm{m}^{-2}\right)$ in areas with extensive bacterial mats $(>50 \%)$. By contrast, the 


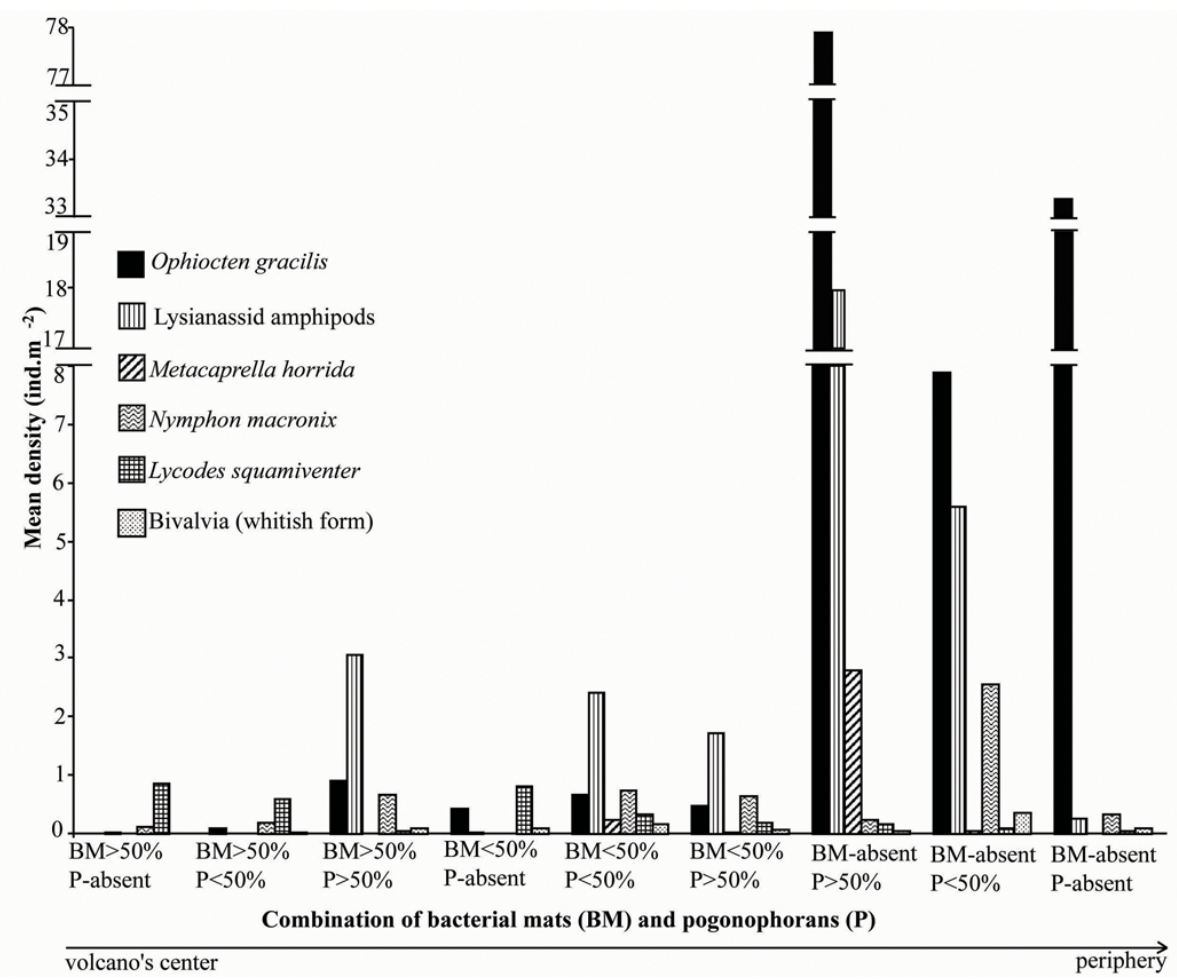

Fig. 5. Mean densities (ind. $\mathrm{m}^{-2}$ ) of selected taxa in areas with combinations of different coverage by bacterial mats (BM) and pogonophorans $(\mathrm{P})$. Relative location within the volcano caldera is shown.

relative contribution of fish was $12 \%\left(0.2 \pm 0.4\right.$ ind. $\left.\mathrm{m}^{-2}\right)$ in areas of extensive pogonophoran settlements $(>50 \%)$ and $6 \%\left(0.1 \pm 0.3\right.$ ind. $\left.\mathrm{m}^{-2}\right)$ in areas without bacterial mats and tube worms. The relative contribution of ophiuroids increased from $0.8 \%\left(0.1 \pm 0.4\right.$ ind. $\left.\mathrm{m}^{-2}\right)$ in areas with extensive bacterial mats to $39 \%\left(40.2 \pm 62.3\right.$ ind. $\left.\mathrm{m}^{-2}\right)$ in areas of extensive pogonophoran fields and up to $87 \%$ $\left(34.4 \pm 21.6\right.$ ind. $\left.\mathrm{m}^{-2}\right)$ in areas without bacterial mats and tube worms (on light-coloured sediments). The highest relative contribution of lysianassids $(26 \%)$ and caprellids $(0.9-2 \%)$ was found in the pogonophoran area.

\subsection{Comparison of megafauna from three zones inside the volcano caldera}

Inside the HMMV caldera the following three main habitats can be distinguished: bacterial mats, pogonophoran settlements and light-coloured sediments (Fig. 7). The habitats are arranged in zones around the volcano centre in a more or less concentric pattern, however, boundaries between zones are not always clear because bacterial mats and pogonophoran colonies may co-occur in different proportions (Fig. 8). Variations in the mean density of selected taxa and area coverage by bacterial mats and pogonophorans in different zones are shown on Fig. 8.

Zone I. A zone of bacterial mats is most clearly distinguished around the caldera centre. The zone is characterised by extensive bacterial mats on grey or yellowish sediment. Megafaunal densities ranged from 0.1 to 52.7 ind. $\mathrm{m}^{-2}$ between individual images (mean $3.3 \pm 6.4$ ind. $\mathrm{m}^{-2}$ ). The fish Lycodes squamiventer reached a density of 0.6 ind. $\mathrm{m}^{-2}$ in this zone.

Zone II. The zone of settlements of siboglinid tube worms (pogonophorans) Archeolinum contortum and Oligobrachia $w e b b i$ is located further away from the centre of the caldera. Most of the megafauna is absent from this zone, whereas the density of pycnogonids, $N$. macronix, caprellids, M. horrida, lysianassid amphipods and bivalve molluscs clearly increased on siboglinid fields. Total megafaunal densities in this zone ranged from 0.1 to 271.2 ind. $\mathrm{m}^{-2}$ between individual images (mean $34.0 \pm 56.0$ ind. $\mathrm{m}^{-2}$ ). Ophiuroid densities ranged from 0 to 248 ind. $\mathrm{m}^{-2}$ between individual images (mean $24.9 \pm 48.1$ ind. $\mathrm{m}^{-2}$ ).

Zone III. The zone of plain light-coloured sediments devoid of bacterial mats and pogonophorans forms the periphery of the caldera. This zone was dominated by the ophiuroid $O$. gracilis. Most of the megafauna taxa, first of all the echinoderms, were abundant in this zone. Total megafaunal densities ranged from 0.1 to 116.3 ind. $\mathrm{m}^{-2}$ between individual images (mean $37.7 \pm 22.3$ ind. $\mathrm{m}^{-2}$ ). Ophiuroid densities varied from 0 to 115.6 ind. $\mathrm{m}^{-2}$ between individual images (mean $35.7 \pm 21.7$ ind. $\mathrm{m}^{-2}$ ). 


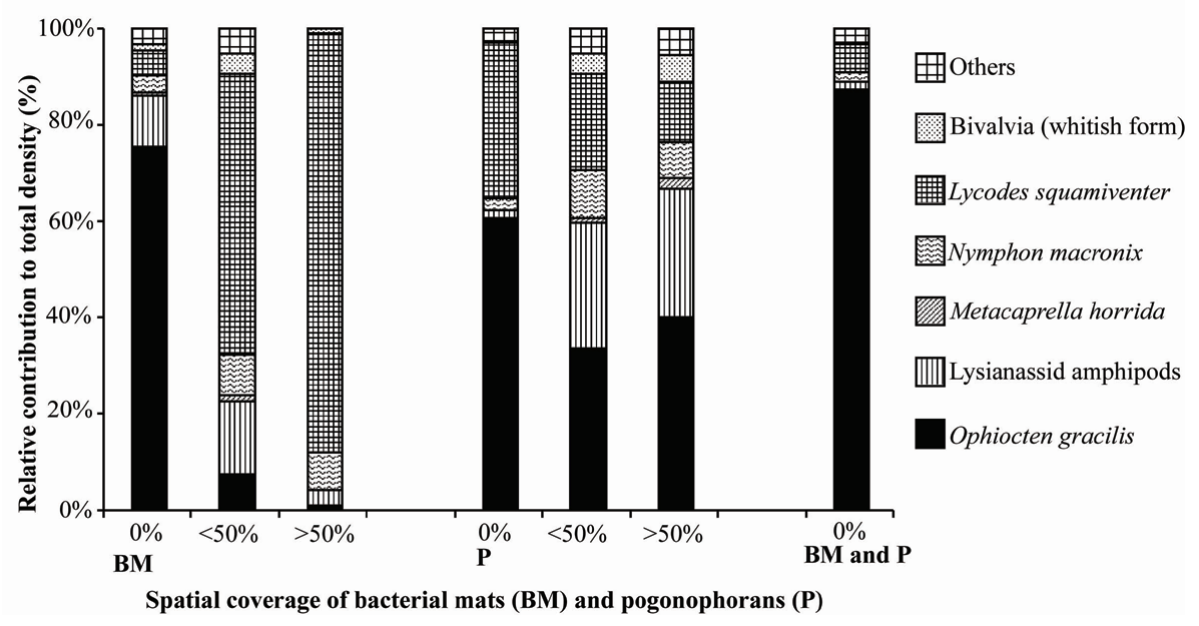

Fig. 6. Relative contribution of the most abundant taxa to total density in areas with different bacterial mat (BM) and pogonophoran (P) cover. Data of three OFOS transects (I, II and III) combined.

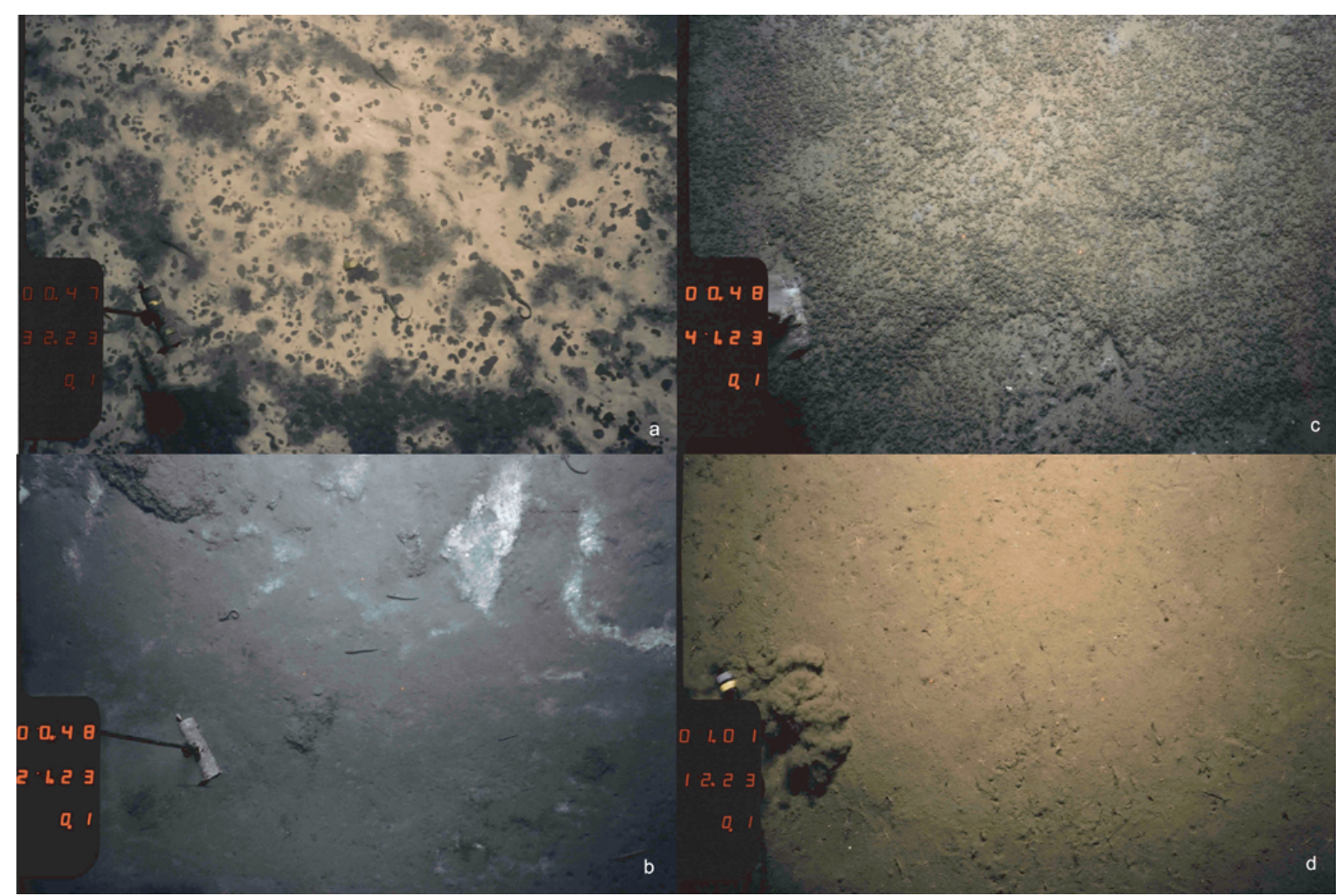

Fig. 7. Images from different habitats. (a) bacterial mat (coverage $>80 \%$ ) with fish Lycodes squamiventer; (b) patches of bacterial mat $(<10 \%)$ on grey sediment, fish Lycodes squamiventer; (c) tube worms Archeolinum contortum ( $>50 \%$ ); (d) plain light-coloured sediments with numerous ophiuroids, Ophiocten gracilis.

Some of the megafauna (mainly relatively large mobile crustaceans and rays) were present throughout the caldera with no clear association to any particular habitat type.

The highest density of non-symbiotrophic megafauna was recorded in the zone of light-coloured sediments, followed by the zone of pogonophoran settlements. The lowest densities were recorded from the bacterial mat zone (Fig. 9). 

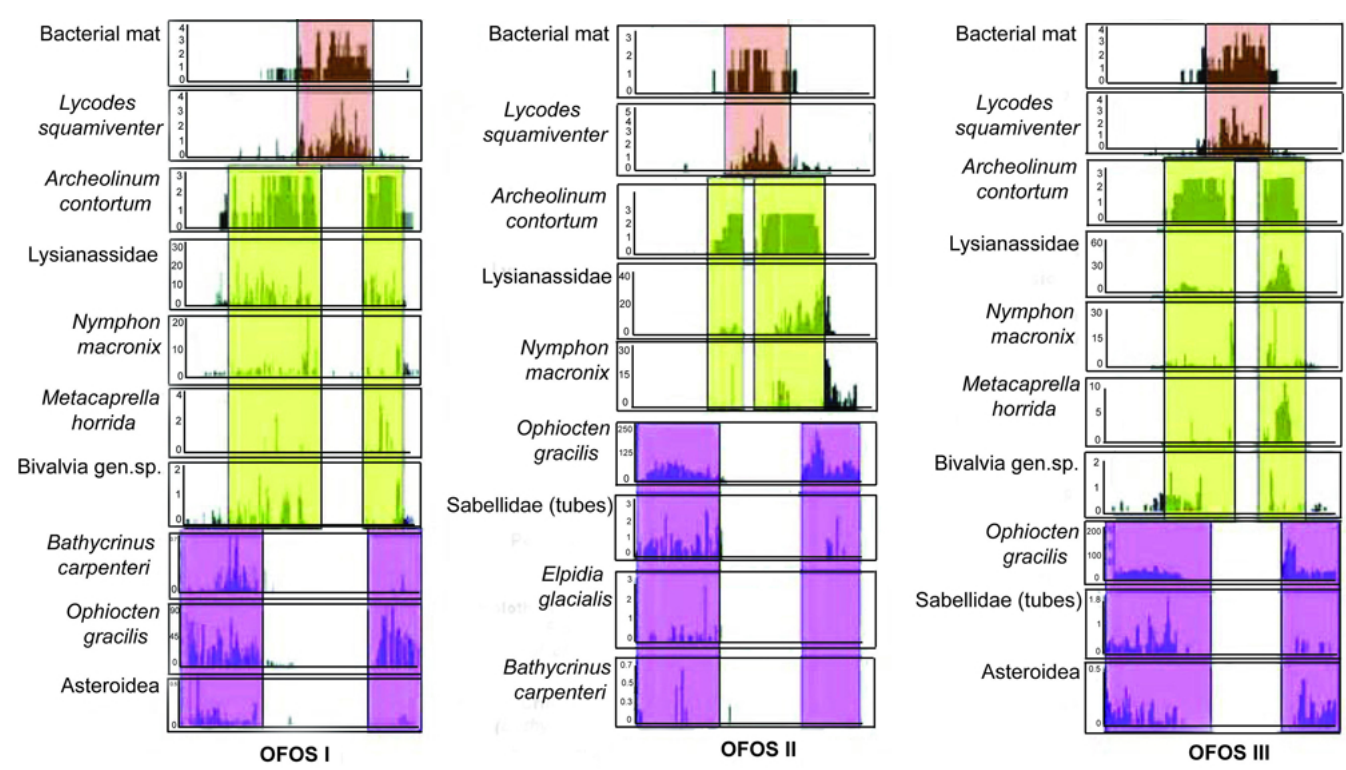

Fig. 8. Variations in mean densities of selected taxa and area coverage of bacterial mats or siboglinids on images along OFOS transects I, II and III. Density in ind. $\mathrm{m}^{-2}$ on the left axis. Area coverage: Bacterial mats: $0-0 \%, 1-<10 \%, 2-10-50 \%, 3-50-80 \%, 4->80 \%$; Archeolinum contortum: $0-0 \%, 1-<10 \%, 2-10-50 \%, 3->50 \%$. Zones are shown in colour: red - bacterial mats, yellow - siboglinid settlements, violet - plain light-coloured sediment.

\subsection{Comparison of the volcano caldera and the background area}

The OFOS IV transect outside the caldera revealed twenty-four species/morphospecies and two morphotypes of megafauna. Eleven taxa were identified either to species or genus level, others were assigned to higher taxa: Porifera (2), Cnidaria (1), Nemertea (2), Polychaeta (2), Gastropoda (1), Bivalvia (1), Pycnogonida (2), Crustacea (4), Ophiuroidea (2), Crinoidea (1), Asteroidea (4), Echinoidea (1) and at least one fish species. Additionally two morphotypes (undetermined sedentary animals) were recorded. Echinoderms (8 species/morphospecies) and sedentary animals (5 species/morphospecies/morphotypes) accounted for the majority of taxa (Table 2). Ten additional species were found in trawl samples (Table 2 in Supplement). However, this number cannot be considered representative since the trawl net was damaged by several large rocks during trawling. Mean megafaunal densities outside the caldera were $25.3 \pm 21.0$ ind. $\mathrm{m}^{-2}$ ranging from 1.9 to 84.0 ind. $\mathrm{m}^{-2}$.

Six taxa accounted for more than $95 \%$ of the total density: O. gracilis, sabellid polychaetes, the sponge Stylocordyla borealis, lysianassid amphipods, unidentified sedentary animals (morphotype 2) and bivalves. Ophiocten gracilis was the most abundant species $(65.7 \%)$.

ANOSIM revealed significant differences in megafaunal composition and density on images taken inside the caldera on light-coloured sediments devoid of bacterial mats and pogonophorans and images outside the caldera (Global $R=$ $0.378,0=0.001)$. SIMPER showed that the following three

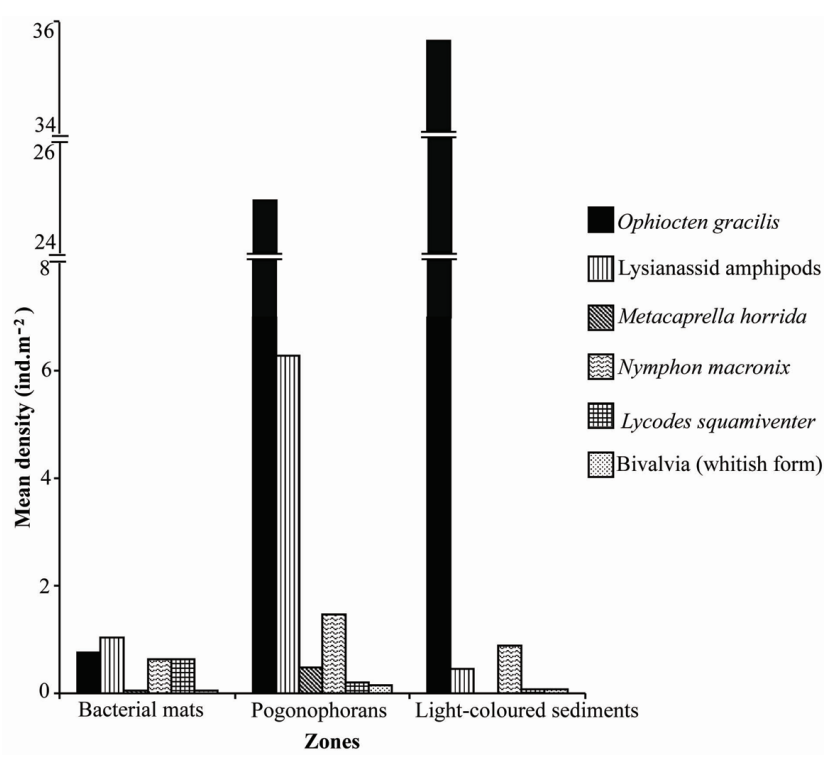

Fig. 9. Mean densities (ind. $\mathrm{m}^{-2}$ ) of selected taxa in different zones of the Håkon Mosby mud volcano. Data of three OFOS transects (I, II and III) combined.

species contributed most to this separation of images: $O$. $\mathrm{gra}$ cilis, sabellid polychaetes and $S$. borealis.

The composition of the dominant taxa in the background area differed from that inside the caldera. Only two taxa, $O$. gracilis and lysianassid amphipods, were abundant in both areas (Table 7). In the background area, other abundant taxa 
included the sabellids, $S$. borealis and unidentified sedentary organisms absent or found in low numbers inside the caldera. The mean density of $O$. gracilis was significantly lower in the background area $\left(22.3 \pm 21.8 \mathrm{ind} . \mathrm{m}^{-2}\right)$ compared to the zone of light-coloured sediments inside the caldera $\left(35.7 \pm 21.7\right.$ ind. $\left.\mathrm{m}^{-2}\right)(M-W: W=29635.0, p=0.00001)$. Similarly, the mean density of lysianassid amphipods was significantly lower in the background $\left(0.3 \pm 0.7\right.$ ind. $\left.\mathrm{m}^{-2}\right)$ compared to the zone of light-coloured sediments inside the caldera $\left(0.5 \pm 1.6\right.$ ind. $\left.\mathrm{m}^{-2}\right)(M-W: W=91731.5$, $p=0.0236$ ) (Table 4).

Mean total megafaunal density was significantly lower in the background $\left(25.3 \pm 21.0\right.$ ind. $\left.\mathrm{m}^{-2}\right)$ compared to the area of light-coloured sediments inside the caldera $\quad\left(37.7 \pm 22.3\right.$ ind. $\left.\mathrm{m}^{-2}\right) \quad(M-W: \quad W=104087.0$, $p<0.00001)$.

In total, 24 taxa were found inside the volcano caldera and 26 outside on the OFOS images. In both areas 19 taxa were present (Table 2). However, sedentary biota, such as sponges, cnidarians and some unidentifiable morphotypes were only recorded in the background area. Based on the equal number of randomly selected images, taxa richness was higher outside the caldera (26) than in the area of light-coloured sediments inside the caldera (21).

Evenness and diversity were significantly higher in the background than on the light-coloured sediments $\left(J^{\prime}=0.4\right.$ vs. $J^{\prime}=0.2 ; \quad H^{\prime}=0.6$ vs. $H^{\prime}=0.2$ and 1 $\lambda=0.3$ vs. $1-\lambda=0.1)(M-W: W=29113.0, p=0.00001$; $W=29899.0, p=0.00001 ; W=29660.5, p=0.00001$, respectively) (Table 3 ).

\section{Discussion}

The Håkon Mosby mud volcano has received considerable attention over the last decade as one of the target areas of ambitious EU-funded programmes such as HERMES and HERMIONE and various nationally funded projects. However, studies on macro- and megafaunal communities inhabiting the HMMV are still very limited and our knowledge of the volcano background community remains poor.

We were able to identify 40 taxa in total (including species, "morphospecies" and "morphotypes") based on images and samples taken inside the volcano caldera. Gebruk et al. (2003) reported 46 macrofaunal benthic taxa from this area, Decker, Olu (2012) and Decker et al. (2012) reported 28 macrofaunal benthic taxa. A large portion of taxa listed by these authors included small and infaunal forms, such as polychaetes and amphipods that are not easily detected on seafloor photographs and were missing in our records. Based on combined data of Gebruk et al. (2003), Decker, Olu (2012), Decker et al. (2012) and our present study, the species inventory of the HMMV comprises at least 80 taxa. In the present study, we added at least 20 species/morphospecies to the inventory: Cnidaria (4), Annelida (4), Sipunculida
(1), Cephalorhyncha (1), Crustacea (1), Echinodermata (6), Pisces (3) (Table 2 in Supplement).

Taxa richness did not differ noticeably inside and outside the caldera: 40 vs. 36 , although the number of species outside the caldera could be higher if three transects (as inside the caldera) had been taken or the sampling effort had been more intense. A photographic survey at the HAUSGARTEN observatory west of Svalbard $(\sim 1300 \mathrm{~m}$ depth) revealed lower taxa richness (12 taxa/morphotypes) (Soltwedel et al., 2009). Thus, Vinogradova et al. (1996) reported 200 benthic taxa based on 22 trawls at the Russian nuclear submarine Komsomolets wreck site at $1700 \mathrm{~m}$ depth in the Bear Island area, approximately 120 miles north of the HMMV on the continental slope. The benthic community at this site (based on the biomass) was termed the "Bathybiaster-OphioctenAmphipoda-Oweniidae" assemblage. Similar to the HMMV, benthos at the Komsomolets site was dominated by echinoderms (primarily asteroids and ophiuroids), amphipods and polychaetes. In our study, in trawl catches outside the caldera ophiuroids and asteroids were also dominant.

Two species of siboglinid tube worms (perviate pogonophorans), Archeolinum contortum and Oligobrachia webbi, dominated inside the caldera. Both genera are common at depths of the Norwegian-Greenland Basin (NGB) and are usually associated with reducing biotopes. They were found at methane seeps at $1230 \mathrm{~m}$ depth on the Vestnesa Ridge (Gebruk et al., 2003) and on the Norwegian slope at the Nyegga site at $\sim 720 \mathrm{~m}$ depth (Krylova et al., 2011). Archeolinum contortum was also abundant at the recently discovered deep-sea hydrothermal vent site 'Loki's Castle' at a depth of $2350 \mathrm{~m}$ at the junction of the Mohn and Knipovich ridges (Pedersen et al., 2010). The species $O$. webbi was reported from the shallower hot vent site on the Mohn Ridge north of Jan Mayen (500-750 m water depth; Schander et al., 2010). Both siboglinid species apparently are highly specialized to reducing habitats and can inhabit their different types: methane seeps and hydrothermal vents, sunken wood and other decomposing organic material (Gebruk et al., 2003).

According to our data, the density and proportions of taxonomic groups noticeably varied between habitats inside and outside the caldera. The megafaunal species observed along OFOS transects could be grouped according to their occurrence in different habitats. Many species abundant outside the caldera and at the inactive periphery of the volcano were either completely absent or very rare in the pogonophoran and bacterial mat zones. Among such species were echinoderms (echinoids, starfish, crinoids and holothurians), polychaetes, sponges and nemertea. An exception was the ophiuroid $O$. gracilis, which was quite abundant in the dense settlements of pogonophorans $(>50 \%)$ without bacterial mats. The mean density of $O$. gracilis in this habitat was higher than in the background: $63.6 \pm 67.8$ ind. $\mathrm{m}^{-2}$ and $22.3 \pm 21.8$ ind. $\mathrm{m}^{-2}$, respectively. A photographic survey at the HAUSGARTEN observatory 
west of Svalbard $(\sim 1,300 \mathrm{~m}$ depth), conducted also on the ARK XIX/3 cruise, revealed slightly lower densities of $O$. gracilis $\left(16.8 \pm 3.7\right.$ ind. $\left.\mathrm{m}^{-2}\right)$ and an aggregated occurrence (Soltwedel et al., 2009). Ophiocten gracilis occurs in a wide range of habitats; this species appears to be very adaptive and opportunistic. In hydrothermal vent habitats on the Mid-Atlantic Ridge ophiuroids (Ophiocten acies) reached densities as high as 80 ind. $\mathrm{dm}^{-2}$ (Gebruk et al., 2000) in the Logatchev area.

Thus, the effect of the mud-volcano environment on benthic communities is expressed in increasing of biomass, changing of taxa composition (absence of some groups known outside the volcano and emergence of some groups unknown outside the volcano) and changing of proportions of most taxonomic groups. The most special groups for HMMV environment excluding symbiotrophic megafauna were pisces Lycodes squamiventer, lysianassid amphipods, pycnogonid Nymphon macronix, caprellid Metacaprella horrida and ophiuroid Ophiocten gracilis.

In the HMMV area both pogonophorans are restricted to the volcano and the nearest surrounding (Gebruk et al., 2003). Populations of the more abundant $A$. contortum cover thousands of square meters of the seabed. The georeferenced video mosaics and detailed spatial analyses by Jerosch et al. (2007) illustrate particularly dense populations of these tube worms in the so-called 'hummocky periphery' of the caldera and estimated the total area covered by tube worms at $275958 \mathrm{~m}^{2}$, by dense bacterial mats (density $>50 \%$ ) at $31435 \mathrm{~m}^{2}$ and the central caldera part at $115165 \mathrm{~m}^{2}$. Our data indicate that the highest densities of $A$. contortum are in areas with bacterial mat coverages of less than $50 \%$ of the sea floor. Our results based on the analysis of 894 images from HMMV disagree with conclusion of Niemann et al. (2006) that sulphide-oxidizing mats and tubeworm colonies are mutually exclusive. A great number of images showed both biota.

Some megafaunal species at HMMV were clearly associated with pogonophorans. Among them were the caprellid amphipod Metacaprella horrida, the pycnogonid Nymphon macronix and lysianassid amphipods. The density of burrowing bivalve molluscs also increased on the pogonophoran fields. Total megafaunal densities of pogonophoran fields would increase dramatically if the tube worms themselves were added to our calculations. However, on the seafloor images it is almost impossible to determine even approximate numbers of tubes, especially when they are curled as in $A$. contortum. Also many tubes in dense populations are empty (A. Gebruk, personal communication, 1998).

Overall, total megafaunal densities clearly increased on the pogonophoran fields ( $>50 \%$ coverage) compared to the background habitat $\left(25.3 \pm 21.0\right.$ ind. $\left.\mathrm{m}^{-2}\right)$ and dropped to minimum values on the bacterial mats $(>50 \%)$. The limited number of megafauna species able to live in a "moderate" reducing environment are apparently capable of taking advantage of low competition in partitioning of resources and reach high population densities. Models based on temperature profiles indicate lower fluid flow rates $\left(0.4 \mathrm{~m} \mathrm{yr}^{-1}\right)$ in the pogonophoran fields compared to those of the centre or bacterial mat zone (Kaul et al., 2006). The increased habitat complexity provided by pogonophorans together with a more stable environment may result in higher megafaunal densities. Furthermore, Niemann et al. (2006) concluded that microbe-invertebrate symbioses have an advantage over free-living microbial populations as they can engineer their environment to increase access to both electron donors and acceptors by special migratory behaviour, mining and pumping.

The bacterial mat zone was characterized by the lowest megafaunal density and species richness. The opposite trend was shown for the density of meiofauna at the HMMV it was the highest in the bacterial mat zone compared to pogonophoran fields and the background (Portnova et al., 2010). In our study, megafaunal density decreased sharply even at low bacterial coverage $(<10 \%)$. The only species with higher densities on bacterial mats was the fish Lycodes squamiventer. This species had significantly higher growth rates at the HMMV compared with conspecifics from HAUSGARTEN caught at comparable depth (Hildebrandt et al., 2011) indicating favourable local growth conditions at the mud volcano. Furthermore, stable isotope analyses showed that the $\delta^{13} \mathrm{C}$ and $\delta^{15} \mathrm{~N}$ in L. squamiventer muscle tissues from the HMMV were significantly lower than those from HAUSGARTEN indicating that the fish from HMMV relied on food linked to the methane-based food web (Gebruk et al. 2003; Bergmann et al. 2009, and unpubl. data). Zoarcidae is a fish family often encountered at hydrothermal vents and cold seeps, with some specialised species that are likely to have adapted to the toxic environment (Desbruyères et al., 2006).

The density of megafauna in our study was relatively high. For example, on the mud volcanoes in the eastern Mediterranean the density of non-symbiotrophic megafauna were two or three orders of magnitude lower (Olu-Le Roy et al., 2004). However, the depth of these volcanoes is greater, approximately from 1700 to $2000 \mathrm{~m}$.

The three habitats (zones) distinguished at the HMMV are arranged in a more or less concentric pattern: the central zone, around it pogonophoran fields and the light-sediment zone in the periphery. The latter two zones harbour a complicated mosaic of bacterial mats. Such a concentric structure of a habitat and community pattern is more typical of hydrothermal vents, centred around hot fluid emissions (Galkin, 2002). For example, Hessler and Kaharl (1995) distinguished "the vent opening, the near-field and the periphery“. This obvious simplification points at pronounced gradients of environmental parameters that are very characteristic of hydrothermal vents and other habitats with focused emission of heat and reduced compounds, one of such habitats being mud volcanoes. At typical cold methane seep sites the pattern of fauna distribution is usually more heterogeneous and is first of all controlled by fluid flow (Sahling et al., 2002; Levin, 2005). 
The central zone of the volcano appears to be devoid of megafauna most likely because of the instability of the environment. Indeed, Feseker et al. (2008) reported an exceptionally high level of mud volcanic activity with temperature gradients of more than $40^{\circ} \mathrm{C} \mathrm{m}^{-1}$ within the upper half meter of the sediments close to the geometric centre of the caldera, frequent mud eruptions of small volume and limited local extent.

The variety of reducing habitats known at present in the Norwegian-Greenland Basin (NGB) includes two "cold" methane seep sites - Nyegga at 710-730 m depth on the Norwegian slope in the Storrega slide area (Ivanov et al., 2007, 2010) and the methane seep area at $1230 \mathrm{~m}$ depth on the Vestnesa Ridge (Gebruk et al., 2003), which includes the relatively hot and active mud volcano (HMMV), a shallow-water hydrothermal vent north of Iceland, Kolbenisey $(\sim 90 \mathrm{~m}$ depth) (Fricke et al., 1989), two upper bathyal hydrothermal vents, Grimsey ( $400 \mathrm{~m}$ ) north of Iceland (Hannington et al., 2001) (no biological investigations yet) and the area north of Jan Mayen on the Mohn Ridge with the fields Trollveggen $(500-560 \mathrm{~m})$, Galionella Garden $(\sim 615 \mathrm{~m})$, Soria Moria I and II (700-750 m) (Schander et al., 2010), and one recently discovered hydrothermal vent site, Loki's Castle, at $2350 \mathrm{~m}$ depth, at the junction of the Mohn and Knipovich Ridges (Pedersen et al., 2010). According to published data, most of the macro- and megafauna of methane seeps and hydrothermal vents in the NGB, including the HMMV, is not specialised to these habitats, it comprises primarily regular background fauna (with exception of two species of pogonophoran tube worms, opportunists of reducing environments). This feature is unusual: in other areas, reducing habitats are dominated by highly specialized megafaunal species restricted in their distribution to a specific reducing habitat or rarely to several of them. In the NGB the only species clearly obligate to methane seeps is the bivalve Isorropodon nyeggaensis (Krylova et al., 2011), representative of the family Vesicomyidae, one of the iconic taxa of reducing environments (Levin, 2005; Desbruyères et al., 2006). The lack of vent/seep specialists in the NGB may result from a young age of fauna: the recent deep-sea benthic fauna north of the Faroe-Iceland Ridge shows signs of origin after the end of the last glacial period (Golikov, 1985; Svararsson et al., 1993).

\section{Supplementary material related to this article is available online at: http://www.biogeosciences.net/10/ 3359/2013/bg-10-3359-2013-supplement.pdf.}

Acknowledgements. We are grateful to the Captain, the officers and the crew of RV Polarstern for their support during the ARK-XVIII/1b, ARK-XX/1, ARK-XXII/1b expeditions. We also thank and the teams of the remotely operated vehicles "Victor
6000" and "Quest 4000" for their support in obtaining samples for ground-truthing. This work was partially supported by HERMES - Hotspot Ecosystem Research on the Margins of European Seas (contract number GOCE-CT-2005-511234), funded by the European Commission's Framework Six Programme and HERMIONE Hotspot Ecosystem Research and Man's Impact on European Seas (contract number 226354) funded by the European Commission's Framework Seven Programme. Financial support also was provided by the Grant 12-05-31066 of RFBR (Russian Federation), Grant 12-05-33049 of RFBR (Russian Federation) and Grant 8664 of Minobrnauki (Russian Federation). Our special thanks to experts for their help in taxonomic identifications: K. Tabachnik and O. Tendal (Porifera), N. Sanamyan (Actiniaria and Ascidiacea), E. Rodriguez (Actiniaria), N. Budaeva and S. Gromisz (Polychaeta), M. Kedra (Sipuncula), E. Krylova (Bivalvia), A. Warén (Mollusca), A. Raiskiy and R. Bramber (Pycnogonida), G. Vinogradov and J.-M. Weslawski (Amphipoda), A. Brandt (Isopoda), J. Guerrero (Tanaidacea), A. Mironov (Echinoidea), D. Piepenburg (Ophiuroidea, Asteroidea), A. Rogacheva (Holothuroidea) and P. R. Möller (Fish). The authors thank Paul Dando for the correction of the style of English and useful comments on the manuscript. We are indebted to anonymous reviewers for improvements to an earlier draft of the manuscript. This is publication no. 31571 of the Alfred Wegener Institute for Polar and Marine Research.

Edited by: R. Serrão Santos

\section{References}

Bergmann, M., Dannheim, J., Bauerfeind, E., and Klages, M.: Trophic relationships along a bathymetric gradient at the deepsea observatory HAUSGARTEN, Deep-Sea Res. Pt. I, 56, 408424, 2009.

Boetius, A., Ravenshlag, K., Schubert, C. J., Rickert, D., Widdel, F., Gieseke, A., Amann, R., Jorgensen, B. B., Witte, U., and Pfannkuche, O.: A marine microbial consortium apparently mediating anaerobic oxidation of methane, Nature, 407, 623-626, 2000.

Boetius, A., Jorgensen, B. B., Amann, R., Henriet, J. P., Hinrichs, K. U., Lochte, K., MacGregor, B. J., and Voodrouw, G.: Microbial systems in sedimentary environments of continental margin, in: Ocean Margin Systems, edited by: Wefer, G. , Billett, D. , Hebbeln, D. , Joergensen, B. B., Schlüter, M., and van Weering, T. C. E., Springer Verlag, Berlin-Heidelberg, Germany, 479-495, 2002.

Bogdanov, Y. A., Sagalevich, A. M., Vogt, P. R., Mienert, Y., Sundvor, E., Crane, K., Lein, A. Y., Egorov, A. V., Peresypkin, V. I., Cherkashev, G. A., Gebruk, A. V., Ginsburg, G. D., and Voitov, D. V.: The Håkon Mosby Mud Volkano in the Norwegian Sea: results of comprehensive investigations with submersibles, Okeanologia, 39, 412-419, 1999 (in Russian).

Clarke, K. R. and Gorley, R. N.: PRIMER v6: user manual/tutorial, PRIMER-E Ltd, Plymouth, 2006.

Crane, K. and Solheim, A.: Sea floor atlas of the northern Norwegian-Greenland Sea, 137, Norsk Polarinstitutt Meddelelser, Oslo, Norway, 172 pp., 1995.

Damm, E. and Budeus, G.: Fate of vent-derived methane in seawater above the Håkon Mosby Mud Volcano (Norwegian Sea), Mar. Chem., 82, 1-11, 2003. 
De Beer, D., Sauter, E., Niemann, H., Witte, U., Schlüter, M., and Boetius, A.: In situ fluxes and zonation of microbial activity in surface sediments of the Håkon Mosby Mud Volcano, Limnol. Oceanogr., 51, 1315-1331, 2006.

Decker, C. and Olu, K.: Habitat heterogeneity influences cold-seep macrofaunal communities within and among seeps along the Norwegian margin. Part II: contribution of chemosynthesis and nutritional patterns, Mar. Ecol., 33, 231-245, 2012.

Decker, C., Morineaux, M., Caprais, J. C., Olu, K., Van Gaever, S., Lichtschlag, A., Gauthier, O., and Andersen, A. C.: Habitat heterogeneity influences cold-seep macrofaunal communities within and among seeps along the Norwegian margin - Part I: macrofaunal community structure, Mar. Ecol., 33, 205-230, 2012.

Desbruyères, D., Segonzac, M., and Bright, M.: Handbook of Deepsea Hydrothermal Vent Fauna, Second completely revised edition, Denisia, 18, 544 pp., 2006.

Dimitrov, L. I.: Mud volcanoes - the most important pathway for degassing deeply buried sediments, Earth-Sci. Rev., 59, 4976,2002 .

Eldholm, O., Sundvor, E., Vogt, P. R., Hielstuen, B. O., Crane, K., Nilsen, A. K., and Gladczenko, T. P.: SW Barents Sea continental margin heat flow and Håkon Mosby Mud Volcano, Geo-Mar. Lett., 19, 29-37, 1999.

Feseker, T., Foucher, J.-P., and Harmegnies, F.: Fluid flow or mud eruptions? Sediment temperature distributions on Håkon Mosby mud volcano, SW Barents Sea slope, Mar. Geol., 247, 194-207, 2008.

Fleysher, P., Orsi, T. H., Richardson, M. D., and Anderson A. L.: Distribution of free gas in marine sediments: a global overview, Geo-Mar. Lett., 21, 103-122, 2001.

Fricke, H., Giere, O., Stetter, K., Alfredsson, G. A., Kristjansson, J. K., Stoffers, P., and Svavarsson, J.: Hydrothermal vent communities at the shallow subpolar mid-Atlantic ridge, Mar. Biol., 102, 425-429, 1989.

Galkin, S. V.: Hydrothermal vent communities of the World Ocean. Structure, typology, biogeography, GEOS, Moscow, Russia, 200 pp., 2002.

Gebruk, A. V., Chevaldonne, P., Shank, T., Lutz, R. A., and Vrijenhoek, R. C.: Deep-sea hydrothermal vent communities of the Logatchev area $\left(14^{\circ} 45^{\prime} \mathrm{N}\right.$, Mid-Atlantic Ridge): diverse biotopes and high biomass, J. Mar. Biol. Assoc. UK., 80, 383-394, 2000.

Gebruk, A. V., Krylova, E. M., Lein, A. Y., Vinogradov, G. M., Anderson, E., Pimenov, N. V., Cherkashev, G. A., and Crane, C.: Methane seep community of the Håkon Mosby Mud Volcano (the Norwegian Sea): composition and trophic aspects, Sarsia, 88, 394-403, 2003.

Golikov, A. N.: Stages and frontiers of the Cenozoic. Analysis of geological time and evolution of marine gastropod fauna, Proceedings of the Zoological Institute, USSR Academy of Sciences, 130, 31-52, 1985 (in Russian).

Hannington, M., Herzig, P., Stoffers, P., Scholten, J., Botz, R., Garbe-Schönberg, D., Jonasson, I. R., Roest, W., and Shipboard Scientific Party: First observations of high-temperature submarine vents and massive anhydrite deposits off the north coast of Iceland, Mar. Geol., 177, 199-220, 2001.

Hessler, R. R. and Kaharl, V. A.: The deep-sea hydrothermal vent community: an overview, in: seafloor hydrothermal systems: physical, chemical, biological, and geochemical interac- tions, Humphris, S. E., Zierenberg, R. A., Mullineaux, L. S., and Thomson, E., American Geophysical Union, Washington, 72-84, 1995.

Hildebrandt, N., Bergmann, M., and Knust, R.: Longevity and growth efficiency of two deep-dwelling Arctic zoarcids and comparison with eight other zoarcid species from different climatic regions, Polar Biol., 34, 1523-1533, 2011.

Hinrichs, K. U. and Boetius, A.: The anaerobic oxidation of the methane: new insights in microbial ecology and biogeochemistry, in: Ocean Margin Systems, edited by: Wefer, G., Billet, D., Hebbeln, D., Jorgensen, B. B., Schlüter, M., and Weering, T. C. E. V., Springer Verlag, Berlin-Heidelberg, Germany, 457-477, 2002.

Hjelstuen, B. O., Eldholm, O., Faleide, J. I., and Vogt, P. R.: Regional setting of Håkon Mosby Mud Volcano, SW Barents Sea margin, Geo-Mar. Lett., 19, 22-28, 1999.

Huguen, C., Mascle, J., Chaumillon, E., Kopf, A. J., Woodside, J., and Zitter, T.: Structural setting and tectonic control of mud volcanoes from the Central Mediterranean Ridge (Eastern Mediterranean), Mar. Geol., 209, 245-263, 2004.

Ivanov, M. K., Limonov, A.F., and Van Weering, T.: Comparative characteristics of the Black Sea and Mediterranean Ridge mud volcanoes, Mar. Geol., 132, 253-271, 1996.

Ivanov, M., Blinova, V., Kozlova, E., Westbrook, G. K., Mazzini, A., Minshull, T. A., and Nouzé, H.: First sampling of gas hydrate from the Vøring Plateau, Eos, Transactions, American Geophysical Union, 88, 209-216, 2007.

Ivanov, M., Mazzini, A., Blinova, V., Kozlova, E., Laberg, J.-S., Matveeva, T., Taviani, M., and Kaskov, N. Seep mounds on the Southern Vøring Plateau (offshore Norway), Mar. Petrol. Geol., 27, 235-1261, 2010.

Jerosch, K., Schlüter, M., Foucher, J.-P., Allais, A.-G., Klages, M., and Edy, C.: Spatial distribution of mud flows, chemoautotrophic communities and biogeochemical habitats at Håkon Mosby Mud Volcano., Mar. Geol., 243, 1-17, 2007.

Kaul, N., Foucher, J. P., and Heesemann, M.: Estimating mud expulsion rates from temperature measurements on Håkon Mosby Mud Volcano, SW Barents Sea, Mar. Geol., 229, 1-14, 2006.

Klages, M., Thiede, J., and Foucher, J.-P.: The expedition ARKTISXIX/3 of the research vessel "Polarstern" in 2003, Reports on Polar and Marine Research, Alfred Wegener Institute for Polar and Marine Research, Bremerhaven, Germany, 488, 346 pp., 2004.

Kohl, B. and Roberts, H.H.: Fossil foraminifera from four active mud volcanoes in the Gulf of Mexico, Geo-Mar. Lett., 14, 126134, 1994.

Kopf, A. J.: Significance of mud volcanism, Rev. Geophys., 40, 1005, doi:10.1029/2000RG000093, 2002.

Krupskaya, V. V., Andreeva, I. A., Sergeeva, E. I., Cherkashev, G. A., and Ivanov M. K.: The Håkon Mosby Mud Volcano (Norwegian Sea): features of a structure and deposit composition, in: Experience of systemic oceanological exploration in Arctic regions, edited by: Lisitsin, A. P. and Vinogradov, M. E., Nauchnyi Mir, Moscow, Russia, 492-502, 2001 (in Russian).

Krylova, E. M., Gebruk, A. V., Portnova, D. A., Todt, C., and Haflidason, H.: New species of the genus Isorropodon (Bivalvia: Vesicomyidae: Pliocardiinae) from cold methane seeps at Nyegga (Norwegian Sea, Voring Plateau, Storrega slide), J. Mar. Biol. Assoc. UK., 91, 1135-1144, 2011. 
Lein, A. Y. and Ivanov, M. V.: Biogeochemical cycle of methane in the ocean, Nauka, Moscow, Russia, 576 pp., 2009.

Lein, A. Y., Vogt, P. R., Crane, K., Egorov, A., Pimenov, N. V., Savvichev, A. S., Ginsburg, G. D., Ivanov, G. I., Cherkashev, G. A., and Ivanov M. V.: Geochemical pecularities of gas-bearing $\left(\mathrm{CH}_{4}\right)$ deposits of the submarmud volcano in the Norwegian Sea, Geohymiya, 3, 230-249, 1998 (in Russian).

Lein, A. Y., Vogt, P. R., Crane, K., Egorov, A., and Ivanov, M.: Chemical and isotopic evidence for the nature of the fluid in $\mathrm{CH}_{4}$ - containing sediments of the Håkon Mosby Mud Volcano, GeoMar. Lett., 19, 76-83, 1999.

Lein, A. Y., Pimenov, N. V., Savvichev, A. S., Pavlova, G. A., Vogt, P. R., Bogdanov, Y. A., Sagalevich, A. M., and Ivanov, M. V.: Methane as a source of organic matter and the hydrocarbon acid of carbonates at a cold seep in the Norwegian Sea, Geohymiya, 3, 268-281, 2000 (in Russian).

Levin, L. A.: Ecology of cold-seep sediments: interactions of fauna with flow, chemistry and microbes, Oceanogr. Mar. Biol., 43, 146, 2005.

Meunier, C., Andersen, A. C., Bruneaux, M., Le Guen, D., Terrier, P., Leize-Wagner, E., and Zal, F.: Structural characterization of hemoglobins from Monilifera and Frenulata tubeworms (Siboglinids): First discovery of giant hexagonalbilayer hemoglobin in the former "Pogonophora" group, Comp. Biochem. Phys. A., 155, 41-48, 2010.

Milkov, A. V.: Worldwide distribution of submarine mud volcanoes and associated gas hydrates, Mar. Geol., 167, 29-42, 2000.

Milkov, A. V., Vogt, P. R., and Cherkashev, G. A.: Sea-floor terrains of Håkon Mosby Mud Volcano as surveyed by deep-tow video and still photography, Geo-Mar. Lett., 19, 143-149, 1999.

Milkov, A. V., Sassen, R., Apanasovich, T. V., and Dadashev F. G.: Global gas flux from mud volcanoes: a significant source of fossil methane in the atmosphere and the ocean, Geophys. Res. Lett., 30, 1037, doi:10.1029/2002GL016358, 2003.

Niemann, H., Lösekann, T., De Beer, D., Elvert, M., Nadalig, T., Knittel, K., Amann, R., Sauter, E. J., Schlüter, M., Klages, M., Foucher, J. P., and Boetius, A.: Novel microbial communities of the Håkon Mosby mud volcano and their role as a methane sink, Nature, 443, 854-858, 2006.

Olu-Le Roy, K., Sibuet, M., Fiala-Médioni, A., Gofas, S., Salas, C., Mariotti, A., Foucher, J. P., and Woodside, J.: Cold seep communities in the deep eastern Mediterranean Sea: composition, symbiosis and spatial distribution on mud volcanoes, Deep-Sea Res. Pt. I, 51, 1915-1936, 2004.

Pedersen, R. B., Rapp, H. T., Thorseth, I. H., Lilley, M. D., Barriga, F. J. A. S., Baumberger, T., Flesland, K., Fonseca, R., FrühGreen, G. L., and Jorgensen, S. L.: Discovery of a black smoker vent field and vent fauna at the Arctic Mid-Ocean Ridge, Nature Communications, 1, 1-6, 2010.

Pimenov, N. V., Savvichev, A. S., Rusanov, I., Lein, A. Y., Gebruk, A. V., and Moskalev, L. I.: Microbial processes of carbon cycles at the base of the food chain of Håkon Mosby Mud Volcano benthic community, Geo-Mar. Lett., 19, 89-96, 1999.

Pimenov, N. V., Savvichev, A. S., Rusanov, I., Lein, A. Y., and Ivanov, M. V.: Microbiological processes of carbon and sulfur cycles at cold methane seeps in the North Atlantic, Microbiologiya, 69, 831-843, 2000 (in Russian).

Portnova, D., Mokievsky, V., and Soltwedel, T.: Nematode species distribution patterns at the Håkon Mosby Mud Volcano (Norwe- gian Sea), Mar. Ecol.-Evol. Persp., 31, 24-41, 2011.

Sahling, H., Rickert, D., Lee, R.V., Linke, P., and Suess, E.: Macrophaunal community structure and sulphide flux at has hydrate deposits from the Cascadia convergent margin, NE Pacific, Mar. Ecol.-Prog. Ser., 231, 121-138, 2002.

Sauter, E. J., Muyakshin, S. I., Charlou, J.-L., Shlüter, M., Boetius, A., Jerosch, K., Damm, E., Foucher, J.-P., and Klages, M. Methane discharge from a submarine mud volcano into the upper water column by gas hydrate-coated methane bubbles, Earth Planet. Sc. Lett., 243, 354-365, 2006.

Schander, C., Rapp, H. T., Bakken, T., Berge, J., Cochrane, S., Kongsrud, J. A., Oug, E., Byrkjedal, I., Cedhagen, T., Fosshagen, A., Gebruk, A., Larsen, K., Obst, M., Pleijel, F., Stöhr, S., Todt, C., Warén, A., Hadler-Jacobsen, S., Keuning, R., Mikkelsen, N. T., Petersen, K. H., Torseth, I., and Pedersen, R. B.: The fauna of hydrothermal vents on the Mohn Ridge (North Atlantic), Mar. Biol. Res., 6, 155-171, 2010.

Sibuet, M. and Olu, K.: Biogeography, biodiversity and fluid dependence of deep-sea cold-seep communities at active and passive margins, Deep-Sea Res. Pt. II, 45, 517-567, 1998.

Smirnov, R. V.: Two new species of pogonophoran from the Arctic mud volcano off northwestern Norway, Sarsia, 85, 141-150, 2000.

Smirnov, R. V.: Morphological characters and classification of the subclass Monilifera (Pogonophora), the problem of evolution of bridle in pogonophora, Biol. Morya_Vlad+, 34, 404-413, 2008 (in Russian).

Soltwedel, T., Portnova, D., Kolar, I., Mokievsky, V., and Schewe, I.: The small-sized benthic biota of the Håkon Mosby Mud Volcano (SW Barents Sea slope), J. Marine Syst., 55, 271-290, 2005.

Soltwedel, T., Jaeckisch, N., Ritter, N., Hasemann, C., Bergmann, M., and Klages, M.: Bathymetric patterns of megafaunal assemblages from the arctic deep-sea observatory HAUSGARTEN, Deep-Sea Res. Pt. I, 56, 1856-1872, 2009.

Svararsson, J., Strömberg, J.-O., and Brattegard, T.: The deep-sea asselote (Isopoda, Crustacea) fauna of the northern seas: species composition, distributional patterns and origin, J. Biogeogr., 20, 537-555, 1993.

Vinogradova, N. G., Turpaeva, E. P., Moskalev, L. I., Galkin, S. V., and Bagirov, N. E.: Species composition of the bottom fauna in the area of study, leading and common forms and modifications of communities, in: Oceanographic research and underwater technical operations at the site of the nuclear submarine Komsomolets wreck, edited by: Vinogradov, M. E., Sagalevitch, A. M., and Khetagurov, S. V., Nauka, Moscow, Russia, 202-206, 1996 (in Russian).

Vogt, P. R., Cherkashev, G. A., Ginsburg, G. D., Ivanov, G., Milkov, A. V., Crane, K., Lein, A. Y., Sundvor, E., Pimenov, N., and Egorov, A.: Håkon Mosby Mud Volcano provides unusual example of venting, EOS, Transactions, American Geophysical Union, 78, 556-557, 1997.

Vogt, P. R., Gardner, J., and Crane, K.: The Norwegian-BarentsSvalbard (NBS) continental margin: introducing a natural laboratory of mass wasting, hydrates and ascent of sediment pore water and methane, Geo-Mar. Lett., 19, 2-21, 1999. 